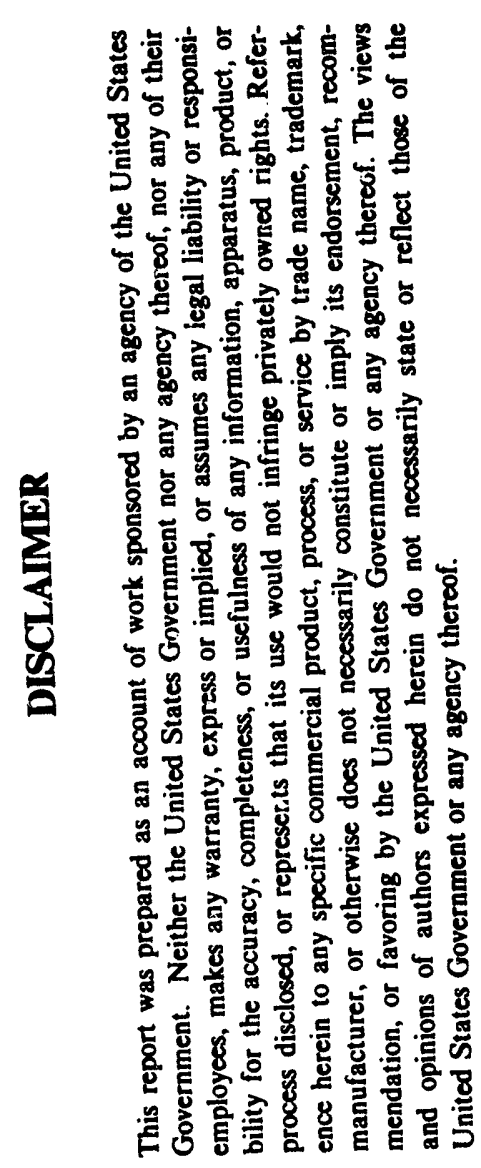

\title{
Preliminary Assessment Report for Fort William Henry Harrison, Montana Army National Guard, Helena, Montana
}

\author{
Prepared for \\ National Guard Bureau, Army Directorate \\ Aberdeen, Maryland
}

July 1993

Prepared by

Applied Geosciences and Environmental Management Section

Environmental Research Division

Argonne National Laboratory

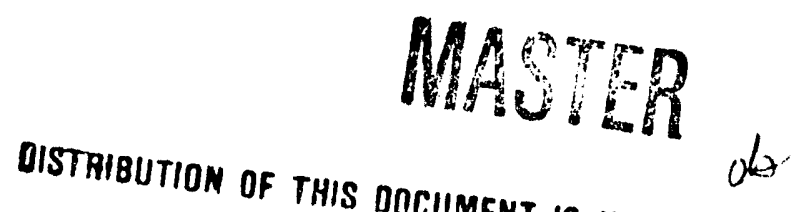




\begin{tabular}{|c|c|c|c|}
\hline \multicolumn{2}{|c|}{ REPORT DOCUMENTATION PAGE } & \multicolumn{2}{|c|}{$\begin{array}{l}\text { FORM APPROVED } \\
\text { OMB No. 0704-0188 }\end{array}$} \\
\hline \multicolumn{4}{|c|}{$\begin{array}{l}\text { Public reporting burden for this collection of information is estimated to average } 1 \text { hour per response, including } \\
\text { the time for reviewing instructions, searching existing data sources, gathering and maintaining the data needed, } \\
\text { and completing and reviewing the collection of information. Send comments regarding this burden estimate or } \\
\text { any other aspect of this collection of information, including suggestions for reducing this burden to Washington } \\
\text { Headquarters Services, Directorate for Information Operations and Reports, } 1215 \text { Jefferson Davis Highway, } \\
\text { Suite } 1204 \text {, Arlington, VA 22202-4302 and to the Office of Management and Budget, Paperwork Reduction } \\
\text { Project (0704-01880), Washington, DC 20503. }\end{array}$} \\
\hline $\begin{array}{l}\text { 1. AGENCY USE (.)NLY } \\
\text { (Leave Blank) }\end{array}$ & $\begin{array}{l}\text { 2. REPORT DATE } \\
\text { July } 1993 \\
\end{array}$ & $\begin{array}{l}\text { 3. REPORT TYPE AND I } \\
\text { Preliminary site visit to }\end{array}$ & $\begin{array}{l}\text { ATES COVERED } \\
\text { complete assessment. }\end{array}$ \\
\hline \multicolumn{3}{|c|}{$\begin{array}{l}\text { 4. TITLE AND SUBTITLE } \\
\text { Preliminary Assessment Report for Fort William Henry Harrison, Montana } \\
\text { Army National Guard, Helena, Montana }\end{array}$} & $\begin{array}{l}\text { 5. FUNDING NUMBERS } \\
\text { MIPR-3788 }\end{array}$ \\
\hline \multicolumn{3}{|c|}{$\begin{array}{l}\text { 6. AUTHOR(S) } \\
\text { John DuWaldt and Tim Meyer }\end{array}$} & MIPR-4188 \\
\hline \multicolumn{3}{|c|}{$\begin{array}{l}\text { 7. PERFORMING ORGANIZATION NAME(S) AND ADDRESS(ES) } \\
\text { Candace M. Rose } \\
\text { Argonne National Laboratory } \\
9700 \text { South Cass Avenue } \\
\text { Argonne. IL } 60439\end{array}$} & $\begin{array}{l}\text { 8. PERFORMING } \\
\text { ORGANIZATION } \\
\text { REPORT NUMBER } \\
\text { None } \\
\end{array}$ \\
\hline \multicolumn{3}{|c|}{ 9. SPONSORING/MONITORING AGENCY NAME(S) AND ADDRESS(ES) } & $\begin{array}{l}\text { 10. SPONSORING/ } \\
\text { MONITORING AGENCY } \\
\text { REPORT NUMBER } \\
\text { IR-CR-9307X } \\
\end{array}$ \\
\hline \multicolumn{4}{|c|}{ 11. SUPPLEMENTARY NOTES } \\
\hline \multicolumn{3}{|c|}{$\begin{array}{l}\text { 12a. DISTRIBUTION/AVAILABILITY } \\
\text { OISTHBUTION OF THIS DOCUMENT IS UNLIMITE }\end{array}$} & $\begin{array}{l}\text { 12b. DISTRIBUTION } \\
\text { CODE }\end{array}$ \\
\hline \multicolumn{4}{|c|}{ 13. ABSTRACT (MAXIMUM 200 WORDS) } \\
\hline \multirow{2}{*}{\multicolumn{3}{|c|}{ 14. SUBJECT TERMS }} & $\begin{array}{l}\text { 15. NUMBER OF PAGES } \\
\text { PA-54 }\end{array}$ \\
\hline & & & 16. PRICE CODE \\
\hline $\begin{array}{l}\text { 17. SECURITY } \\
\text { CLASSIFICATION OF } \\
\text { REPORT } \\
\quad \text { Unclassified }\end{array}$ & $\begin{array}{l}\text { 18. SECURITY } \\
\text { CLASSIFICATION OF } \\
\text { THIS REPORT } \\
\quad \text { Unclassified }\end{array}$ & $\begin{array}{l}\text { 19. SECURITY } \\
\text { CLASSIFICATION OF } \\
\text { ABSTRACT } \\
\quad \text { Unclassified }\end{array}$ & $\begin{array}{l}\text { 20. LIMITATION OF } \\
\text { ABSTRACT }\end{array}$ \\
\hline
\end{tabular}




\section{Contents}

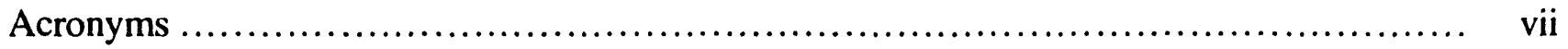

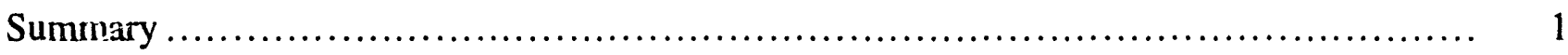

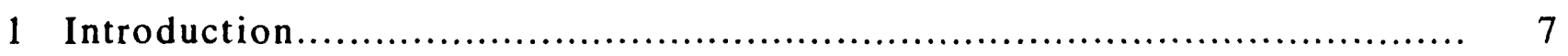

1.1 Authority for the Preliminary Assessment $\ldots \ldots \ldots \ldots \ldots \ldots \ldots \ldots \ldots \ldots \ldots \ldots \ldots$

1.2 Objectives ....................................................................... 7

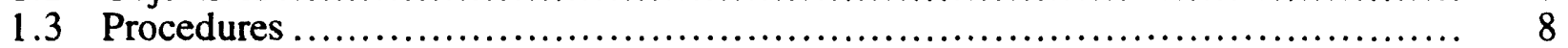

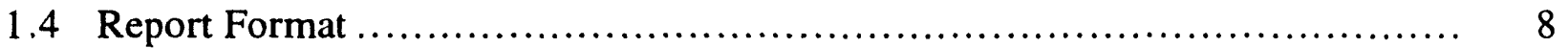

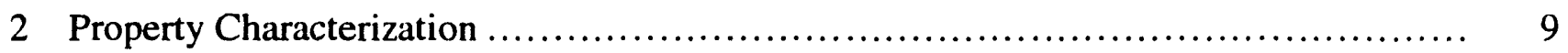

2.1 General Property Information............................................... 9

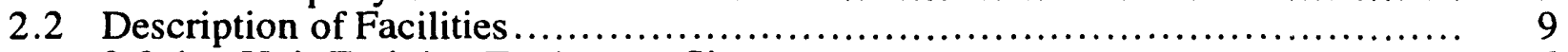

2.2 .1 Unit Training Equipment Site .................................... 16

2.2.2 Combined Support Maintenance Shop ............................... 17

2.2.3 Southwest Asia Rebuild Center ................................... 18

2.2.4 Williams Street Gravel Pit .................................................. 18

2.2.5 Old Ordnance Burial Trench........................................ 19

2.2.6 Scattered Pits Area................................................. 19

2.2.7 Landfill Burial Cells.............................................. 19

2.2.8 Railroad Track Spill Area ............................................... 20

2.2 .9 Ranch Trash Sites .............................................................. 20

2.2 .10 Muscle Mountain Dumps ............................................ 20

2.2 .11 Burn Pit ......................................................... 21

2.3 Property History ................................................................. 21

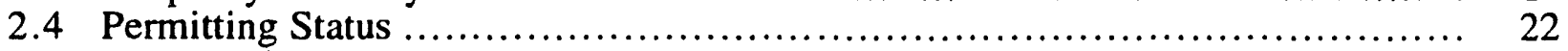

2.5 Surrounding Environment and Land Use ................................. 23

2.5.1 Demographics and Land Use..................................... 23

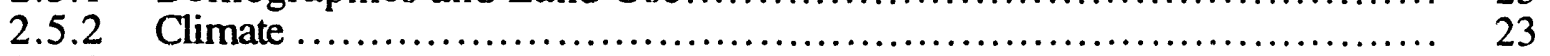

2.5.3 Surface Water and Physiography .......................................... 24

2.5.4 Groundwater and Hydrogeology ...................................... 25

2.5.5 Sensitive Environments............................................... 31

3 Environmentally Significant Operations ...................................... 32

3.1 Southwest Asia Rebuild Center ............................................. 32

3.2 Landfill Burial Cells ........................................................ 32

3.3 Old Ordnance Burial Trench..................................................... 33

3.4 Scattered Pits Area..................................................................... 33

3.5 Williams Street Gravel Pit ............................................................... 33

3.6 Railroad Track Stains Area ...................................................... 34

4 Known and Suspected Releases ............................................. 35

4.1 Releases to Groundwater ................................................ 35

4.2 Releases to Surface Water .............................................. 35

4.3 Releases to Soil ................................................................ 35

4.4 Releases to Air .................................................................. 36

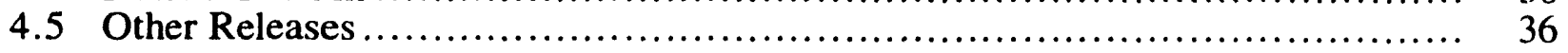




\section{Contents (Cont.)}

5 Human and Environmental Receptors........................................ 37

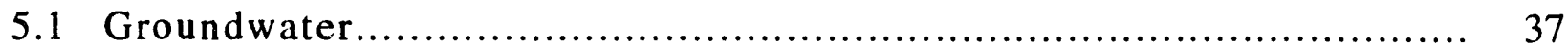

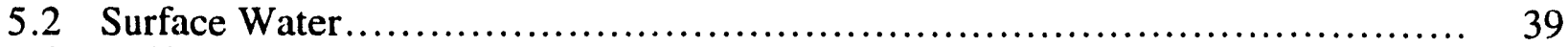

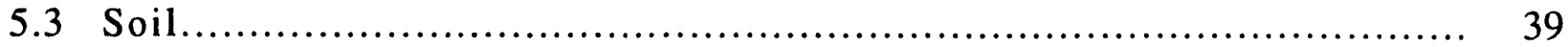

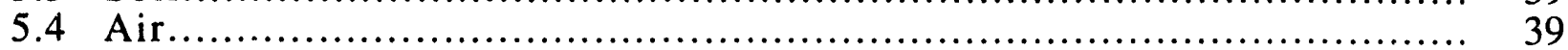

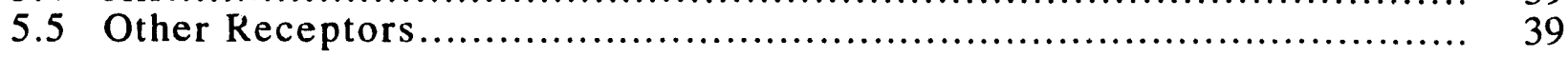

6 Preliminary Assessment Findings and Conclusions ............................. 40

6.1 Summary of Preliminary Assessment Findings ............................. 40

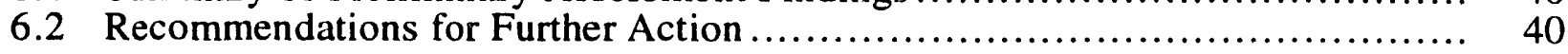

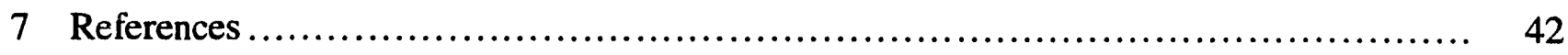

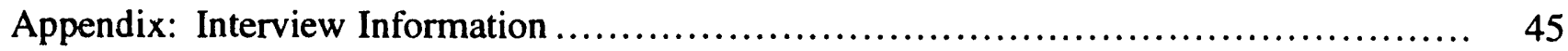

Figures

1 General Location of Fort William Henry Harrison $\ldots \ldots \ldots \ldots \ldots \ldots \ldots \ldots \ldots \ldots \ldots \ldots$

2A Map Detail of Fort William Henry Harrison with Locations of Environ mentally Significant Operations ...................................... 13

2B Detail of Fort William Henry Harrison Cantonment with Locations of Environmentally Significant Operations and Underground Storage Tanks............ 14

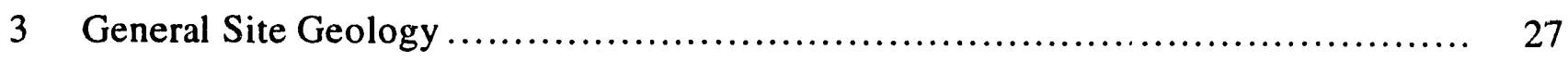

4 Groundwater Surface Elevation and Flow Direction................................ 29

5 Four-Mile Radius Map Showing Groundwater Wells......................... 38

\section{Table}

1 Identifying Information for Fort William Henry Harrison ...................... 


\section{Acronyms}

CERCLA

CLP

CSMS

DoD

DRMO

EPA

ESO

FISP

gpm

IRP

MCL

MDHES

MTARNG

PA

RCRA

SES

SWAREB

SWMU

TCE

TDS

TSDF

USGS

UST

UTES

V.A.
Comprehensive Environmental Response, Compensation, and Liability Act Contract Laboratory Program

Combined Support Maintenance Shop

U.S. Department of Defense

Defense Reutilization Marketing Organization

U.S. Environmental Protection Agency

environmentally significant operation

Facility Inventory and Stationing Plan

gallons per minute

Installation Restoration Program

maximum contaminant level

Montana Department of Health and Environmental Sciences

Montana Army National Guard

preliminary assessment

Resource Conservation and Recovery Act

State Environmental Specialist

Southwest Asia Rebuild Center

Solid Waste Management Unit

trichloroethylene

total dissolved solids

Treatment, Storage or Disposal Facility

U.S. Geological Survey

underground storage tank

Unit Training Equipment Site

Veterans Administration 


\section{Preliminary Assessment Report for Fort William Henry Harrison, Montana Army National Guard, Helena, Montana}

\section{Summary}

This report presents the results of the preliminary assessment (PA) conducted by Argonne National Laboratory at a Montana Army National Guard (MTARNG) property near Helena, Montana. Preliminary assessments of federal facilities are being conducted to compile the information necessary for completing preremedial activities and to provide a basis for establishing corrective actions in response to releases of hazardous substances. The principal objective of the PA is to characterize the site accurately and determine the need for further action by examining site activities, quantities of hazardous substances present, and potential pathways by which contamination could affect public health and the environment. This PA satisfies, for the Fort William Henry Harrison property, requirements of the Department of Defense Installation Restoration Program.

Fort William Henry Harrison is a 1,592-acre site located in the west central portion of Montana, approximately $1.5 \mathrm{mi}$ northwest of the city of Helena, in Lewis and Clark County. The facilities reviewed in this PA include buildings and grounds within the Fort William Henry Harrison cantonment and ranges and other facilities within the Fort William Henry Harrison property boundaries. This report does not include assessment of the Veterans Administration facilities adjacent and contiguous to Fort William Henry Harrison. The environmentally significant operations (ESOs) associated with the property are:

1. Southwest Asia Rebuild Center,

2. Landfill Burial Cells,

3. Old Ordnance Burial Trench,

4. Scattered Pits Area, 
5. Williams Street Gravel Pit, and

6. Railroad Track Stains Area.

The review of both historical and current practices at the property indicates that the Fort William Henry Harrison property may pose potential risk to human health or the environment. No areas or situations suggesting the need for any immediate or emergency removal action were identified during this PA. Of particular concern is a suspected release(s) of hazardous substances to the shallow groundwater from one or more of the ESOs. All six areas of concern are alleged locations of former waste disposal or chemical/fuel spills. These six areas of concern are clustered in the northern half of the Fort William Henry Harrison cantonment, located on the west side of Williams Street in the northeastern portion of the post. Although some aspects of these potential release sources are not well documented, the following facts are relevant:

- Personnel have shown through interview and photographic evidence that Comprehensive Environmental Response, Compensation, and Liability Act wastes were interred in Landfill Burial Cells in the cantonment. Independent aerial photography confirms the presence of these landfill cells.

- Ordnance suspected to contain a high explosive component is alleged to have been buried at the Old Ordnance Burial Trench location. Degradation of the ordnance may have released heavy metals and the nitrogen compound constituents that make up the high explosive to the soil, where it is available to the shallow groundwater.

- The Williams Street Gravel Pit is alleged to have been an area of past solid waste disposal. Although field observation of this location during the site visit did not disclose telltale signs of hazardous waste disposal, the coarseness of the native subsurface material suggests that rapid migration would occur if any water-soluble hazardous wastes were deposited in this area.

- The railroad siding adjacent to the Southwest Asia Rebuild Center buildings T503 through T506 may have been the source of historic fuel/chemical spills from railroad cars delivering material to the post. Again, this material could have infiltrated the subsurface and reached the unconfined, water table aquifer. 
- Trichloroethylene (TCE), trichloroacetic acid (TCA), and similar common industrial cleaning agents have been used at Fort William Henry Harrison.

- Recent USGS sampling of near-downgradient shallow groundwater shows the presence of TCE similar to those known to have been used, and still used, at the post.

- Residences near Fort Wi'iiam Henry Harrison and downgradient from potential contaminant source areas use shallow wells to obtain drinking water.

It can be concluded from this information that hazardous waste disposed at Fort William Henry Harrison may have entered the shallow groundwater and migrated off-site where it poses a long-term threat to human health and the environment. As a result of the findings of this investigation, the following recommendations are offered:

1. Perform an initial contaminant verification study to confirm the presence of contamination in target wells, including the off-site irrigation well known to be contaminated, and to identify which source areas have contaminated groundwater beneath them. The latter should be accomplished by installing a limited number of groundwater monitoring wells in close proximity to the most suspect source areas and obtaining groundwater samples for analysis.

2. Design and implement a sampling plan to locate contaminated subsurface geologic and aquifer materials at potential source areas. The Landfill Burial Cells, Southwest Asia Rebuild Center dry well, and Old Ordnance Burial Trench areas should be sampled on a priority basis. Landfill cells should be surveyed to locate buried drums and to define specific cell location and dimensions using an appropriate mix of metal detection/magnetometry and electromagnetic geophysics. Soils and groundwater near burial cells should be sampled to characterize waste constituents. Analytical parameters for soils and shailow groundwater should include the standard Superfund screening analytes for Contract Laboratory Program (CLP) volatile organic compounds, semivolatile organic compounds, and metals (CLP inorganic compounds) with emphasis on chlorinated solvents. In addition, organic constituents of typical ordnance should be included as malytes, as should typical constituents of Stoddard solvent not included in th : CLP lists of organic compounds. 
If samples from the priority areas show significant concentrations of hazardous substances, the three remaining areas should be sampled to complete information on waste volume and hazardous substance concentrations. Information developed through sampling of soil and wastes will be used to develop hazard ranking system waste characteristics for the source and attribute groundwater contamination to the site.

3. Design and implement a sampling plan to locate groundwater contaminant plume(s) that can be linked to specific ESOs identified at Fort William Henry Harrison. It is recommended that initial plume identification and source tracing be conducted in the most cost-effective manner available - through use of an auger/hydropunch-type sampling technique. If resampling existing wells confirms the existence of off-site contamination, a groundwater monitoring program will be installed. Groundwater samples should be initially acquired in a narrow grid pattern superimposed on a line connecting the location of kn ıwn well contamination downgradient from the site to each of the two priority ESOs. Contaminant information developed from initial sampling should be used to (1) locate other groundwater samples to establish all sources contributing to plume(s) and (2) locate a limited number of groundwater monitoring wells to develop data on plume movement and extent so that recovery wells or other aquifer remedial actions can be planned. In addition, if hazardous substances are identified in aquifer materials or groundwater, groundwater from the nearest domestic wells should be sampled for hazardous constituents. Likewise, on-site irrigation wells located in the cantonment should be sampled to determine if they are contaminated and what effect they are having on contaminant movement in the subsurface.

The above recommendations should be considered as sequential steps in a single expanded site inspection.

In conclusion, although no analytical or health effect evidence is avai'able to establish that the identified ESOs are a source of contaminant release to the air, soil, or surface water, the history of land disposal at the installations presents the likelihood of release to the groundwater and the potential for release to all soil and surface water in the future. In addition, the current practice of disposing of TCE in the Combined Support Maintenance Shop "sump" makes the sump a candidate source of TCE identified in downgradient groundwater. Overall, the results of this study 
establish the need to reconfirm the presence of off-site groundwater contamination, and further investigation to fully characterize, through sampling, the hazardous constituents of the identified six ESOs and the location, composition, and extent of groundwater contaminant plumes that may be emanating from them. This sampling should also consider the potential release of contaminants to the soil and surface water both on-site and locally off-site. 


\section{Introduction}

This document is a report of the preliminary assessment (PA) conducted by Argonne National Laboratory at the Montana Army National Guard (MTARNG) property known as Fort William Henry Harris $\mathrm{n}$, located approximately $1.5 \mathrm{mi}$ northwest of Helena, Montana.

\subsection{Authority for the Preliminary Assessment}

The National Guard Bureau, Army Directorate, has engaged Argonne to perform PAs of selected ARNG properties. These assessments are being done in a manner consistent with both the U.S. Department of Defense (DoD) Installation Restoration Program (IRP) and the U.S. Environmental Protection Agency's (EPA's) Puiential Hazardous Waste Site Preliminary Assessment Guidance. Preliminary assessments of ARNG properties are conducted under the authority and direction of the IRP; the Comprehensive Environmental Response, Compensation, and Liability Act (CERCLA or, more commonly, Superfund); and the Superfund Amendments and Reauthorization Act of 1986 (Public Law 99-499).

\subsection{Objectives}

This PA report is based on existing information from the ARNG records that were made available to Argonne investigators and from other sources. Although this PA effort did not extend to the generation of new data, it nonetheless identifies areas where existing data are incomplete, unreliable, or ambiguous and recommends ways to address such shortcomings.

The objectives of the PA are to satisfy requirements of the IRP and to

- Identify and characterize the environmentally significant operations (ESOs),

- Identify property areas or ESOs that may require a site investigation,

- Identify ESOs or areas of environmental contamination that may require immediate removal, 
- Identify properties for which no further action is needed, and

- Provide information sufficient to prescore the site with the EPA's PA Scoresheets (1991).

\subsection{Procedures}

The PA began with a review of ARNG files located at the MTARNG Headquarters in Helena, Montana, from March 22 to 24, 1993. A site visit was conducted on March 22 and 23. 1993, to obtain additional information through direct observation and interviews with personnel familiar with the property and its operations. Other relevant information was obtained on March 8 and 18 from the U.S. Geological Survey (USGS) library and Earth Science Information Center in Denver, Colorado; and from the Montana Geological Survey, Montana State Highway Department, Montana Natural Heritage Program, and the Montana Department of Natural Resources and Conservation in Helena, Montana, on March 23 and 24.

\subsection{Report Format}

This PA report presents a summary and evaluation of the data relevant to the PA for this property. Section 2 describes the property and its surrounding environment and land uses. Section 3 identifies and characterizes the ESOs at the site. Section 4 discusses known and suspected releases to the environment, and Section 5 discusses potential human and environmental receptors that could be exposed to such releases. Section 6 summarizes the findings and conclusions, discusses the quality and reliability of the supporting information, identifies areas requiring further action, and (as appropriate) suggests how such actions can be accomplished. Section 7 lists pertinent materials reviewed. The Appendix gives interview information. 


\section{Property Characterization}

\subsection{General Property Information}

Fort William Henry Harrison is a major training area operated by the MTARNG on approximately 1,592 acres or $2.49 \mathrm{mi}^{2}$ located northwest of Helena in west-central Montana. Latitude and longitude at the center of the post is $46^{\circ} 37^{\prime} 31^{\prime \prime}$ North and $112^{\circ} 06^{\prime} 37^{\prime \prime}$ West. The rectangular survey coordinates for the post are Town 10 North, Range 4 West, Sections: SE 1/4 section 4, NE 1/4 section 9, section 10, W 1/2 section 15, E1/2 section 16, SE 1/4 section 17, $\mathrm{N} \mathrm{1/2} \mathrm{section} \mathrm{2!,} \mathrm{and} \mathrm{NW} \mathrm{1/2} \mathrm{NW} \mathrm{1/4} \mathrm{section} \mathrm{22.} \mathrm{Primary} \mathrm{access} \mathrm{to} \mathrm{the} \mathrm{site} \mathrm{from} \mathrm{Helena} \mathrm{is} \mathrm{via}$ Williams Street, which runs north-south along the east boundary of the post. Figure 1 shows the general locaticn of the installation in comparison to local physiography and municipalities, and Table 1 lists pertinent location, ownership, and point of contact information. Figures 2A and 2B show details of Fort William Henry Harrison, the cantonment, major facilities, and ESOs.

\subsection{Description of Facilities}

The major facility areas within Fort William Henry Harrison that are potential sources of CERCLA contaminant releases are the cantonment, the Test Track Two area, the Ammunition Storage/Tactical Training areas, and the Live Fire Ranges. Each of these areas includes at least one ESO; the ESOs are discussed in greater detail below. Locations in relation to the cantonment and other landmarks are shown in Figure 2A.

The post cantonment contains approximately 100 buildings that house administrative and engineering offices, training facilities, thrift stores, mess hall, equipment storage, and officer and enlisted personnel housing. External to the cantonment are range areas including an ammunition storage bunker area and vehicle and aviation training areas. An area of grazing land known as the Head Ranch lies northeast of the cantonment and is split by Sevenmile Creek. Currently, the Head Ranch area is leased for cattle grazing. However, few post structures are located outside the cantonment. 


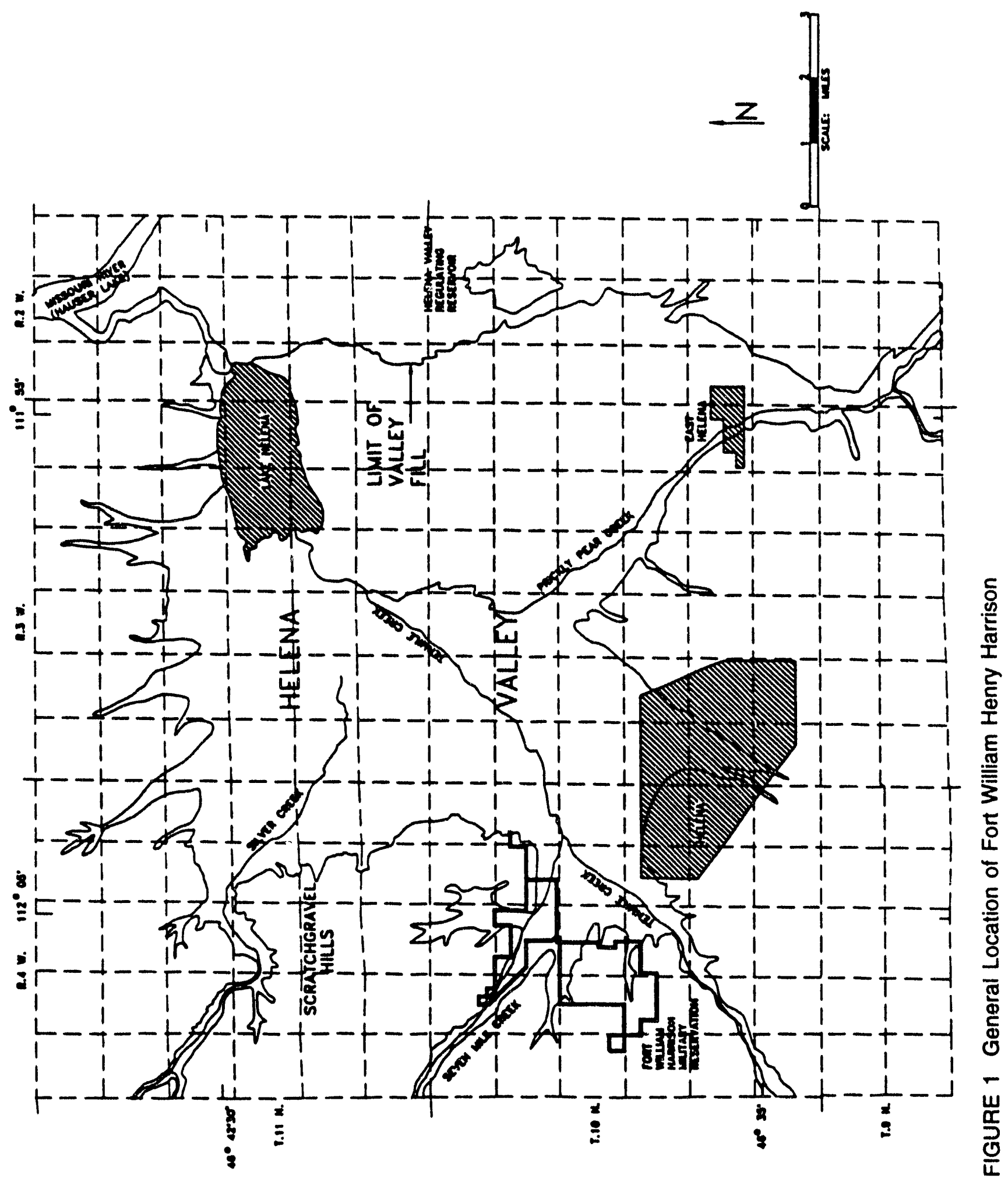


TABLE 1 Identifying Information for Fort William Henry Harrison

Installation address

Section

FISPa installation number

Commander

Types of facilities

License information

Geographic location

Latitude

Longitude

Township and range
Fort William Henry Harrison

Williams Street

Helena, IJontana 59601

$46^{\circ} 37^{\prime} 31^{\prime \prime} \mathrm{N}$

$112^{\circ} 06^{\prime} 37^{\prime \prime} \mathrm{W}$

SE 1/4, Section 4

NE 1/4, Section 9

Section 10

W $1 / 2$, Section 15

E $1 / 2$, Section 16

SE 1/4, Section 17

$N$ 1/2, Section 21

NW 1/2, NW 1/4, Section 22

T10N, R4W

30080

MG John E. Prendergast

1100 North Main Street

Helena, Montana 59604-4789

Ammunition Storage Area

Test Track One

Test Track Two

Live Fire Ranges

Unit Training Equipment Site

Combined Support Maintenance Shop

Southwest Asia Rebuild Center

Williams Street Gravel Pit

Old Ordnance Burial Trench

Scattered Pits Area

Landfill Burial Cells

Railroad Track Stains Area

Ranch Trash Sites

Muscle Mountain Dumps

Burn Pit

Initial license

DA(S) 45-108-ENG-1382 (24 Sep 66)

Amendment \#1

Amendment \#2

Amendment \#3

Removes 25 temporary hutments ( 1 Jan 68 )

Removes 40 temporary hutments (30 Jun 69)

Removes acres conveyed to State of Montana and removes 113 temporary hutments (4 May 69)

Amendment \#4 Extends license to 23 Sep 76 (24 Sep 71) 
TABLE 1 (Cont.)

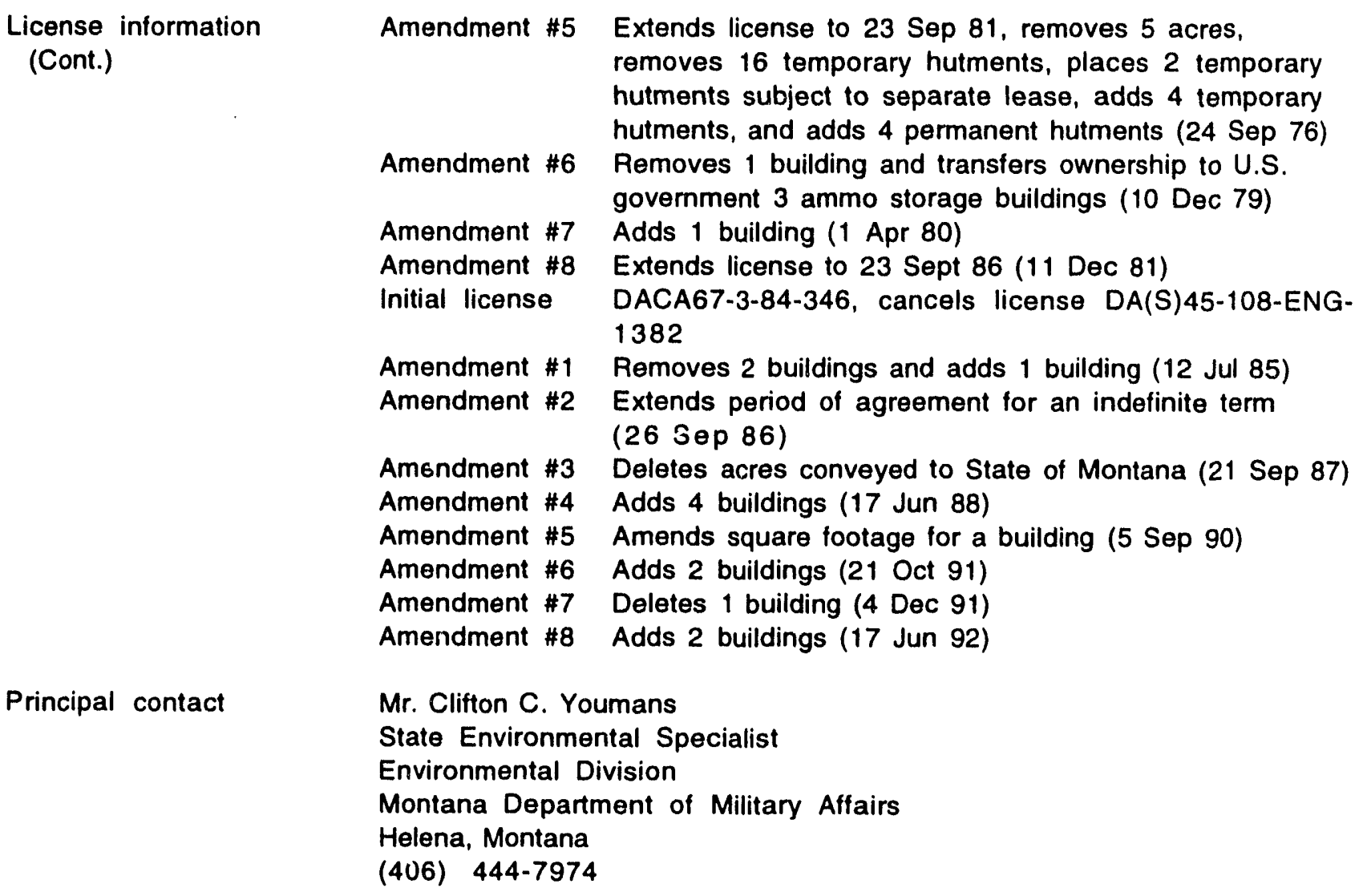

a Facility Inventory and Stationing Plan. 


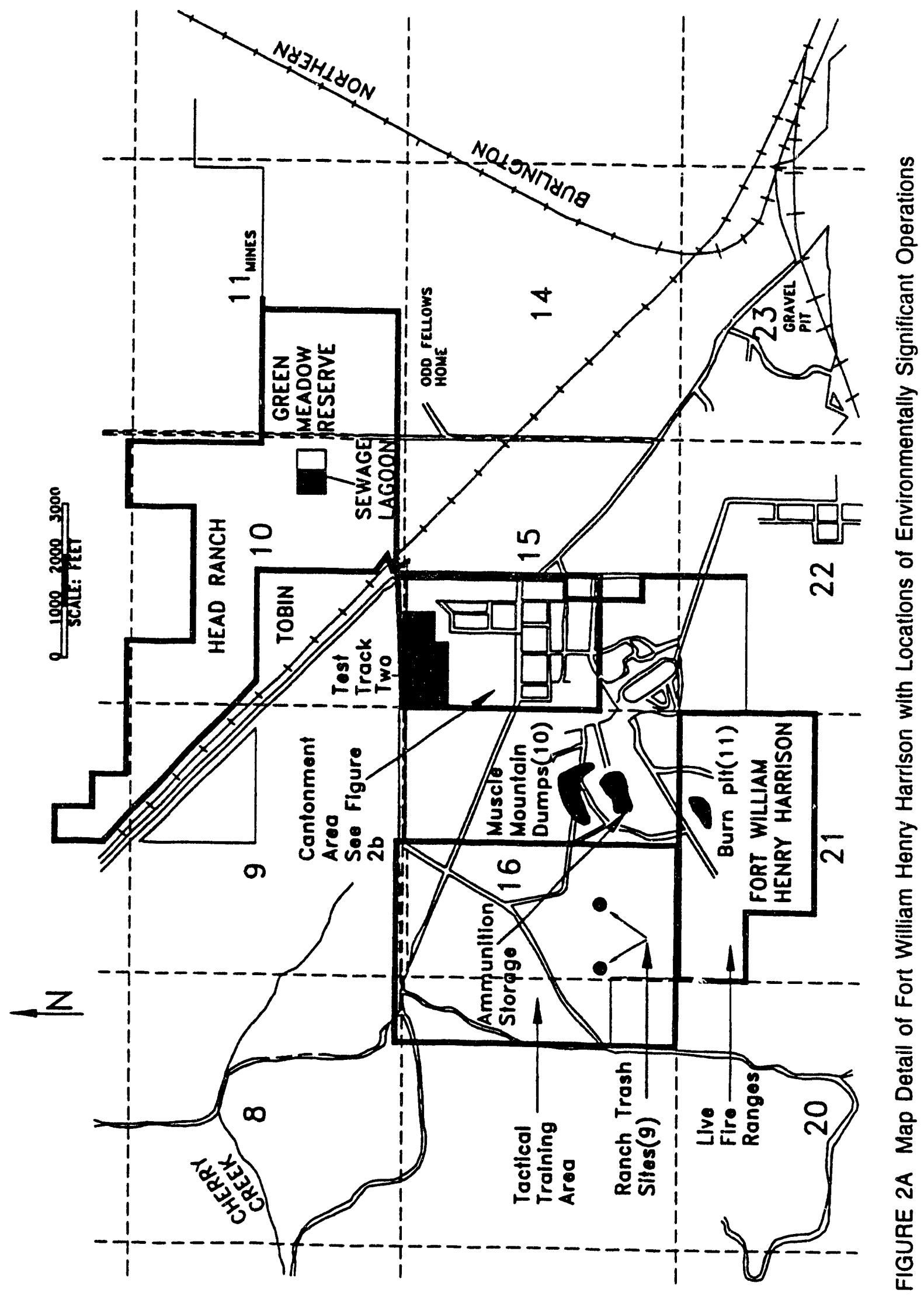




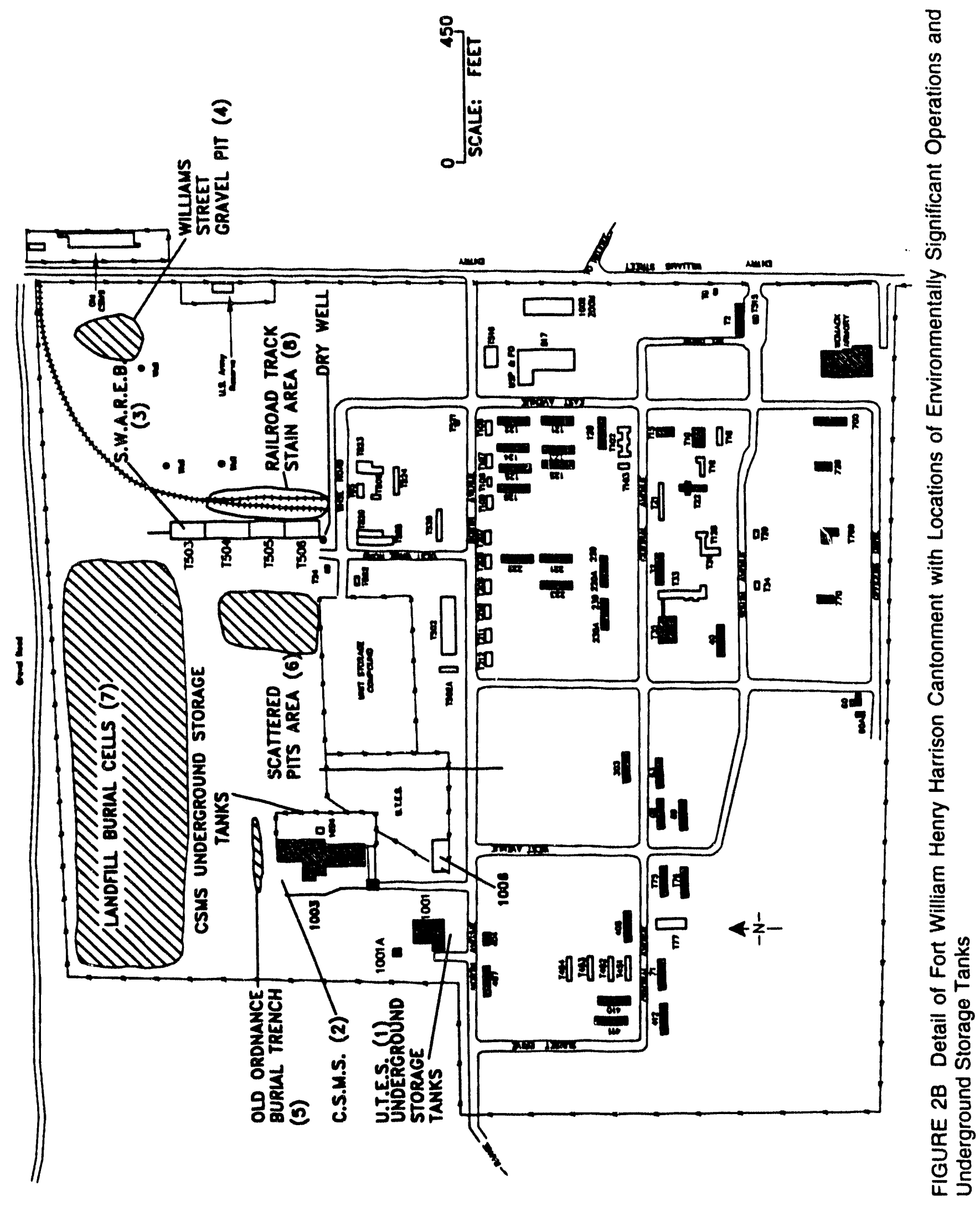


Drinking water is supplied to Fort William Henry Harrison by the city of Helena via a service pipeline. Building heat is provided by natural gas via pipeline. The post has utilized an on-post evaporation sewage lagoon system since the 1950 s to manage waste water. Sewage is collected through 8-in. lines and delivered to two lagoons on the Head Ranch area through a 12-in. line. The sewage treatment system is owned and operated by the Veterans Administration. Storm water conveyances are limited to reinforced concrete and corrugated metal pipe linking storm water detention areas within the cantonment. No subsurface piping to convey storm water is in place due to the low 2-year 24-hour precipitation values (3-4 and $1.5 \mathrm{in}$., respectively). Solid waste generated at the post is sent to the Lewis and Clark County landfill, although waste disposal from approximately the early 1960s through mid 1970s was accomplished through landfilling on the north half of the cantonment (Section 3). It is suspected that RCRA-type hazardous waste from shops that could not be profitably recycled was also interred in on-site landfills or sent to the sewage lagoons during this period.

Current hazardous waste disposal consists of monthly accumulations of less than $1,000 \mathrm{~kg}$ that are transferred to the Defense Reutilization Marketing Organization (DRMO) at Malmstrom Air Force Base in Great Falls, Montana. More information related to hazardous waste is provided in Section 2.4, "Permitting Status," and in Sections 2.2.1 through 2.2.3 regarding specific facilities.

Within the following four operations areas on Fort William Henry Harrison are specifıc facilities of interest:

Cantonment:

1 Unit Training Equipment Site (UTES)

2 Combined Support Maintenance Shop (CSMS)

3 Southwest Asia Rebuild Center (SWAREB)

4 Williams Street Gravel Pit

5 Old Ordnance Burial Trench

6 Scattered Pits Area 
7 Landfill Burial Cells

8 Railroad Track Stains Area

Test Track Two:

(7) Landfill Burial Cells

Ammunition Storage/Tactical Training Areas:

9 Ranch Trash Sites

10 Muscle Mountain Dumps

Live Fire Ranges:

\section{Burn Pit}

Figures 2A and 2B show the general layout of Fort William Henry Harrison and identify major post areas that contain sites scrutinized in this PA, including the cantonment, the head ranch area, the ammunition storage area, the tactical training area, test track two, and the live fire ranges. Figure 2B shows detail of the cantonment where all of the ESOs are located. The two figures show the locations of the 11 facilities reviewed as potential CERCLA sites.

\subsubsection{Unit Training Equipment Site}

The UTES is located within the cantonment on the north side of Sananandra Drive. The activities associated with the UTES take place in Buildings P1001, P1001A, and P1006 and the staging/storage area enclosing P1006 (Figure 2B). UTES has been in place since 1984, and typical hazardous waste generated included chlorinated solvents and waste oil. UTES currently houses two 6,000-gal underground storage tanks (USTs) for fuel (diesel and unleaded gasoline), and one 500-gal aboveground tank to collect waste oil. 
The primary function of UTES is to provide storage for vehicles and equipment used by MTARNG. UTES also performs routine inspections and first-level maintenance of vehicles and equipment. First-level maintenance extends to activities such as fluid level maintenance, battery charging and replacement, windshield wiper and light replacement, and other mechanical and electrical component repair. Waste types and volume generated from first-level maintenance are limited. The post is currently projecting that it will obtain small-quantity Resource Conservation and Recovery Act (RCRA) "C" generator status in the near future, although the post is currently a large-quantity generator due to multiyear accumulated volume, as described in Section 2.4, "Permitting Status." Historically, oily wastes from site activities were conveyed by floor drain through an oil/water separator to an underground 500-gal tank. Residual water was sent to the sanitary sewer, and the oil collection tank would be pumped once a month by a commercial waste oil collector. The underground tank has been removed, and closure has been accepted by the Montana Department of Health and Environmental Sciences (MDHES). Currently, floor drains convey waste oils to a 500-gal aboveground tank. UTES is a satellite accumulation area for RCRA hazardous waste generated within this shop.

\subsubsection{Combined Support Maintenance Shop}

The CSMS is located in the cantonment on the east side of Menton Street in Building 1003 and the adjacent fenced pavement area directly east of Building 1003 (Figure 2B). The shop was opened in 1987 and has been operational to the present. The CSMS performs higher-level maintenance and refurbishment of vehicles and equipment for MTARNG. CSMS activities include repair/rebuilding of engines, transmissions, radiators, and other mechanical systems. Support activities include solvent and steam cleaning of equipment, sandblasting, vehicle body repair, painting, machining, carpentry, electronics/communications repair, welding and brazing, and sheet metal fabrication.

Used motor oil from CSMS activities was collected by hand and poured into an underground tank. Tank contents would be collected each month by a commercial oil collector. An oil/water separator collects liquids from trench drains and sends the aqueous portion to the sewage lagoon. The separator is cleaned once every six months by a commercial oil collector. CSMS has a satellite accumulation area and houses the post's Hazardous Waste Storage Facility. The Hazardous Waste Storage Facility is a prefabricated, single-story, corrugated steel structure with secondary containment, a fire suppressant system, and a fourteen 55-gal barrel capacity. 
CSMS was the source of a major UST spill of diesel and unleaded gasoline in 1987. In total, 2,000 gal of diesel fuel and 2,000 gal of unleaded gasoline were accidentally delivered into shallow wells adjacent to newly installed USTs on the east side of CSMS. Although the fuels penetrated the subsurface to a depth of $34 \mathrm{ft}$, the limited information available suggested that little or no free product was encountered during soil removal and testing. The site was remediated by removing contaminated soil and landfarming at a remote portion of the post. All remedial activities were performed with direction and concurrence from the MDHES (Montana Department of Military Affairs 1987). Two monitoring wells were established approximately 100-300 ft from the release site. The first well was screened from 252 to $260 \mathrm{ft}$ below ground surface. A second well was established to $52 \mathrm{ft}$ below ground surface. These wells were used to establish that cleanup criteria had been met for groundwater and that the source of contamination had been removed (Montana Department of Military Affairs 1987).

\subsubsection{Southwest Asia Rebuild Center}

The SWAREB provides maintenance and rebuilding of vehicles returned from the Desert Storm operation. SWAREB occupies Buildings T503 through T506 located north of Colle Ferro Avenue and adjacent to the double north/south railroad siding (Figure 2B). These shop buildings have been used for maintenance activities since World War II. SWAREB generally performs vehicle maintenance and refurbishment activities such as painting and parts replacement, similar to activities carried out at UTES and CSMS. Although oily wastes generated at SWAREB are currently sent through the sanitary sewer to the post's sewage lagoons, the SWAREB shop historically used dry wells to dispose of liquid wastes until the current sewage lagoon system became functional. The dry wells were located at the south end of Building 506 (Figure 2B). Because the sewage lagoons were constructed in the 1950s, dry well usage was probably terminated during that decade. The dry wells were terminated by filling with cement plugs and can be located today by the cement pads covering their surface.

\subsubsection{Williams Street Gravel Pit}

The Williams Street Gravel Pit is an area of gravel excavation located on the west side of Williams Street within the cantonment area, north of the U.S. Army Reserve building (Figure 2B). This area is currently used for vehicle "hasty" decontamination exercises. "Hasty" decontamination practice simulates rapid cleaning of radionuclide and biologically contaminated debris from armored vehicles. The process uses approximately $200 \mathrm{gal}$ of water. Currently, the gravel pit 
contains surface scattering of solid waste (wood/metal/concrete). Little is known of the history of this excavation; it does not exist in a 1968 aerial photograph of the cantonment. No records exist of burial activities at this location, but MTARNG environmental staff have expressed concern regarding possible debris burial at this location.

\subsubsection{Old Ordnance Burial Trench}

A single or double length trench alleged to contain ordnance recovered from ranges was identified in the area due north of the CSMS within the cantonment (Figure 2B). One interviewee suggested that ordnance buried at this location included projectiles containing small amounts of high explosive (DuWaldt 1993). An existing U-shaped pipe frame located approximately $200 \mathrm{ft}$ north of CSMS was identified as the location of two trenches. It is alleged that one trench extends east from the pipe frame and a second trench extends west from the frame. No surface features indicative of burial activities were observed.

\subsubsection{Scattered Pits Area}

Interviewees identified an area generally located within the cantonment due west of SWAREB buildings as an area containing "pits" where "scrap iron" was buried and dating into the 1960s (Figure 2B). The process used to conduct burial operations consisted of opening a hole and leaving it uncovered until refuse had filled it. The unmanaged nature of this procedure suggests that unassigned waste could have been placed in these excavations.

\subsubsection{Landfill Burial Cells}

The landfill burial cells area is located within the cantonment, generally north of the area between CSMS Building 1003 and SWAREB complex Buildings T503 through T506 (Figure 2B). Interviewees alleged that a series of burial trenches containing solid waste, and including 55-gal and smaller-sized drums of unknown contents, was interred in 40 to 50 cells (DuWaldt 1993). One interviewee who participated in this landfilling activity stated that the landfill burial cell area was the primary post waste disposal area and that waste from all portions of the post was interred at this location. This area was in operation from at least 1964 through the mid 1970s. Visual examination of this area during the site visit did not reveal surface features indicative of burial cells. However, a 1968 aerial photograph shows a 93-ft open trench at this location. The single open 
trench is consistent with an interviewee's statement that burial cells were created and filled one at a time.

\subsubsection{Railroad Track Spill Area}

A railroad track siding to the Burlington Northern Railroad mainline that passes Fort William Henry Harrison on the northeast is located directly adjacent to SWAREB buildings T503 through T506 (Figure 2B). The siding enters the installation at its northeast corner and runs for approximately $4,500 \mathrm{ft}$, terminating at Colle Ferro Avenue. Historic use of this siding included delivery of visiting units, including special forces training units. Interviewees suggested that rail cars on this siding were the source of historic spills and soil staining (DuWaldt 1993). The siding is not currently in use.

\subsubsection{Ranch Trash Sites}

Two historic ranch refuse sites were identified within the Tactical Training Area located due west and upslope of Muscle Mountain (Hill 1263). Their approximate location is indicated in Figure 2A. Interviewees stated that the two areas consisted of solid waste/timber discarded during ranching activity. These activities preceded post-World War II waste disposal activities of most concern to the present study (DuWaldt 1993).

\subsubsection{Muscle Mountain Dumps}

Muscle Mountain is a 1,262-m hilltop centered in the Ammunition Storage Area approximately $0.25 \mathrm{mi}$ west of the Veterans Administration hospital located south of the cantonment (Figure 2A). Ammunition bunkers for ammunition/chemical/ordnance storage are located along the base perimeter of the north, west, and southwest sides of Muscle Mountain. In addition to the storage areas, a water cistern is located at the top of Muscle Mountain. A dispersed area of historic solid waste dumping is situated on the north side of the hill's base, below the storage bunkers, and along the eastern base of the hill. An intermittent tributary to Tenmile Creek runs through the dump area north of Muscle Mountain. Visual survey of these two dump areas showed the surface to contain brick piles, unidentifiable metal debris, evidence of solid waste burning, domestic use glass containers from earlier in the century, small amounts of medical waste, cinders from coal burning, and asphalt shingles. The Fort Harrison historian identified this 
location as containing primarily historic/native solid waste, dating from the turn of the century (DuWaldt 1993).

\subsubsection{Burn Pit}

A fire training pit was located in a draw approximately $0.2 \mathrm{mi}$ south of Muscle Mountain in the Live Fire Ranges area (Figure 2A). A dump area also existed adjacent to this pit, although the contents and origin of this waste material could not be specified. Currently, the burn pit has been excavated, drummed, and disposed of as RCRA hazardous waste via shipment to DRMO. Excavation occurred to the vertical and horizontal extent of contamination as determined by visual examination. No soil samples were analyzed to verify the level of cleanup. The dump has been removed and the area graded and replanted. The area has had an initial seeding and will be reseeded during summer 1993 (DuWaldt 1993).

\subsection{Property History}

Fort William Henry Harrison was authorized by Congress in 1892; the authorization ordered that the Army installation be located near Helena, Montana. The original land set-aside included 1,040 acres for the reservation and 2,770 acres for water supply (State of Montana, Department of Military Affairs 1990). This military reservation was a consolidation and vestige of 35 posts and encampments supporting the frontier population of Montana. The original Fort Harrison was constructed from 1884 to 1896 and included sewer and water systems (State of Montana, Department of Miiitary Affairs 1990). The Montana National Guard used the facility in 1911 for shooting contests. Use of Fort William Henry Harrison as a military camp was modified in 1919 when the Bureau of Public Health Service was authorized to develop the site for hospital purposes. Facilities were expanded again from 1925 to 1928, culminating in the development of a complete summer camp. Summer camps for the MTARNG were held here from 1929 to 1940. During the early 1940s, the active military used Fort Harrison for transportation and K-9 units. From 1944 to 1947, the facility received little attention because of greater utilization of large coastal posts to achieve military goals.

In 1947, the MTARNG resumed activities at Fort William Henry Harrisou and has been the host organization to the present. The post has been continuously occupied from 1948 to the present (State of Montana, Department of Military Affairs 1990). Today the site is used for annual training in combat and combat support. The installation includes the Montana Military Academy, vehicle 
maintenance activities, and live fire and artillery test ranges. The facility has supported field activities by various Special Forces groups, ARNG, Army Reserve, winter infantry training, Army communications and logistics units, Air Force Security, and Navy See Bees units (State of Montana, Department of Military Affairs !990).

\subsection{Permitting Status}

Fort William Henry Harrison is currently permitted as a RCRA large-quantity generator of hazardous waste by the Montana Department of Health and Environmental Sciences, Solid and Hazardous Waste Bureau. The post's RCRA hazardous waste generator number is MT821183080. The site does not operate as a RCRA Treatment, Storage or Disposal Facility (TSDF) and is not permitted as such. Two hazardous waste satellite accumulation points are currently used, one located within the UTES storage area and the second at CSMS. Hazardous waste generated at site facilities is accumulated for less than 90 days of storage and then disposed of with proper manifesting via a commercial contractor through DRMO. The post's Hazardous Waste Storage Facility is located at CSMS and consists of a state-of-the-art prefabricated shed that meets RCRA generator storage requirements, including secondary containment and fire suppression capabilities. This storage area has a fourteen 55-gal drum capacity. The site generator status is expected to remain small quantity in the future as backlogged waste is removed and pollution prevention techniques are implemented to limit waste volumes (DuWaldt 1993). RCRA " $\mathrm{C}$ " waste accumulation and shipment to disposal have been sporadic during the past decade. Multiyear "turn-ins" occurred in 1988 and 1993. The 1988 turn-in consisted of 1,1,1-trichloroethane, solvents and paint thinners, and cadmium-contaminated hydraulic fluid. The 1992 turn-in consisted of similar materials, and in 1993 environmental staff discovered $2.5 \mathrm{gal}$ of the acutely hazardous waste herbicide 2,4,5-T, which was sent to DRMO. The post has strengthened its environmental staff since 1992 and is aggressively correcting RCRA progra: * deficiencies. For instance, starting in 1992, the post has replaced halogenated solvents, such as 1,1,1-trichlorethane, with nonhazardous materials such as Simple Green and Citra Clean. There are no identified, active Solid Waste Management Units (SWMUs) at Fort William Henry Harrison. Nonhazardous solid waste is removed to the Lewis and Clark County landfill or to DRMO.

Waste water from sanitary discharges is conducted to two sewage lagoons operated by the Veterans Administration. These lagoons are operated as evaporation ponds and do not have an 
operating permit or a permitted outfall. However, they are under the scrutiny of the county sanitarian.

The site contains several USTs registered with the MDHES, effective through December 1993. USTs are located at the CSMS and UTES (Figure 2B). The UTES uses two 6,000-gal USTs for diesel fuel and gasoline and has one 500-gal aboveground tank to contain used oil. The CSMS currently has two 2,000-gal diesel USTs.

\subsection{Surrounding Environment and Land Use}

\subsubsection{Demographics and Land Use}

The on-post population at Fort William Henry Harrison consists of approximately 700 workers, including military and civilian personnel. The post can also accommodate 310 troops in temporary facilities; therefore, the full-capacity total is 1,031 personnel. The post has housing for 450 troops (Fort William Henry Harrison Facilities Management Office 1993). 1990 census data show a population of 24,569 residing within the city of Helena boundary and a total population of 47,495 in Lewis and Clark County (U.S. Department of Commerce 1993). The estimated 4-mi radius population is 18,388 , which includes two-thirds of the city of Helena and the hamlets of Broadwater and Iron.

Land use in the Helena Valley except for Helena, the state capitol, is agricultural. The area consists of short-grass grassland and acres in agricultural grains and livestock grazing surrounded by low mountains dominated by coniferous forests. Stands of deciduous trees, primarily willow and cottonwood, and several small lakes are located near Fort William Henry Harrison.

\subsubsection{Climate}

The Helena Valley has a semiarid climate. Average annual precipitation at the Helena Regional Airport weather station located in the south-central part of the valley is 10.85 in., with the greatest monthly precipitation in May, June, and July (Cordell 1971). In contrast, precipitation in the mountains surrounding the Helena Valley can exceed 30 in. per year. Mean annual free-water-surface evaporation is about 35.5 in., three times the annual precipitation. Daily air temperatures extremes range from $-35^{\circ} \mathrm{F}$ in midwinter to $100^{\circ} \mathrm{F}$ in midsummer. The area is subject 
to infrequent hailstorms and tornadoes and is susceptible to flash flooding from locally heavy rainstorms. Brisk westerly and northwesterly winds are common in this area, particularly in the late winter and early spring. The warm Chinook winds tend to provide relief from the cold in the winter, and the resulting warm spells tend to prevent the accumulation of a persistent snow cover.

\subsubsection{Surface Water and Physiography}

Fort William Henry Harrison is located on gently sloping pediments bounded by the foothills of the Rocky Mountains to the south and west, Scratchgravel Hills to the north, and the flat expanse of the $80-\mathrm{mi}^{2}$ Helena Valley to the east (Figure 1). The Continental Divide is found about $15 \mathrm{mi}$ west of the valley, and the mountains reach a height of $5,100 \mathrm{ft}$ within $4 \mathrm{mi}$ of the site. Fort William Henry Harrison lies at an elevation of $4,000 \mathrm{ft}$ above mean sea level in an area of pediment gravels between two of the principal streams draining into Helena Valley, Sevenmile Creek to the north and Tenmile Creek to the southeast. The area at the junction of these two streams has been subject to waterlogging in the past, due to increased infiltration of water from irrigation combined with the change in grade from the sloping pediment deposits at the edge of the foothills to the flat alluvial plain (Lorenz and Swenson 1951).

Four streams provide most of the surface water flow into Helena Valley. The largest is Prickly Pear with a mean annual flow of 48,000 acre-ft from the south, followed by Tenmile Creek from the southwest (18,600 acre- $\mathrm{ft}$ ), Sevenmile Creek from the west $(4,900$ acre-ft), and Silver Creek from the northwest (1,600 acre-ft). Intermittent streamflow and ephemeral runoff from the hillsides adjacent to the valley-fill also supply surface water to the valley. Additional surface water is brought into the valley from the Missouri River via diversion to the Helena Valley Regulating Reservoir. An annual average of 63,100 acre-ft from the Missouri River is released to an extensive network of irrigation canals during the irrigation season. Major agricultural crops are winter wheat, potatoes, sugar beet, barley, and oats. Hay is produced as fodder for the large herds of livestock raised in the area. All streams eventually discharge into Lake Helena at the east end of the valley. Lake Helena discharges to the Missouri River.

The major streams in the vicinity of Fort William Henry Harrison are Sevenmile Creek and Tenmile Creek. Sevenmile Creek flows $1 \mathrm{mi}$ north of the cantonment and drains an area of about $47 \mathrm{mi}^{2}$ before joining Tenmile Creek about a mile east of the property. Tenmile Creek has a catchment area of $98 \mathrm{mi}^{2}$ and flows through the town of Helena before reaching the Sevenmile Creek confluence. The continuation of Tenmile Creek joins Lake Helena about 6 mi downstream. 
A number of ephemeral streams that originate in the foothills west of Fort William Henry Harrison cross the cantonment. The most significant of these is Cherry Creek, which crosses the northern part of the property before dissipating in the coarse pediment and alluvial deposits east of the site. Soils at the site are derived from alluvial sand, silt, and gravel and can be classified as desert soils. They support tall grasses, such as the bunch wheat grass and the fescues. The lower valley areas support short grasses, sedges, wire grass, and slough grass on the wet bottom land.

\subsubsection{Groundwater and Hydrogeology}

Information on the regional hydrogeology of the Helena Valley was derived from a review of the USGS publications authored by Lorenz and Swenson (1951), Moreland and Leonard (1980), and Briar and Madison (1992). The Helena Valley is an intermountain basin that resulted from extensional tectonic movement that began about 50 million years ago during the Eocene Epoch. Renewed faulting and basin subsidence about 16 million years ago, during middle Miocene time, formed the present-day Helena basin from the pre-existing Eocene regional basin. The depth to the bedrock floor of the basin is estimated to be $6,000 \mathrm{ft}$. The Helena Valley is an active seismic area that experienced a severe earthquake in 1935, probably due to movement along faults that lie to the west-southwest and southeast of Helena.

Regional Hydrogeology. Little detail is available on the stratigraphy of the unconsolidated sediments that fill the basin below a depth of a few hundred feet because the prolific shallow aquifer system has made deeper drilling unnecessary. By comparison with other intermountain basins in Montana, the oldest unconsolidated deposits are probably a relatively thin section of Eocene conglomerate unconformably overlain by a thick sequence of fine-grained lacustrine ash and volcaniclastic sediments, with local lenses of gravel and coarse-grained alluvial fan deposits. These sediments were eroded, folded, and tilted before being buried by a thick sequence of Miocene fine- to coarse-grained sediments. The top of these Tertiary sediments now: lies about $100 \mathrm{ft}$ below the surface of the Helena Valley.

Extensive pediments de reloped along the edge of the valley during the Pliocene Epoch, and Quatemary streams deposited channel-fill and alluvial-plain sediments on the surface of the valley. The stratified Quaternary alluvial deposits of gravel, sand, silt, and clay yield abundant water to shallow wells throughout the valley. 
Regional Aquifer Characteristics. Stratified lenses of cobbles, gravel, and sand with abundant intercalated clay and silt make up the upper few hundred feet of the Helena valley-fill aquifer system. Discontinuity of the clay and silt layers allows hydraulic connection of the coarse-grained, water-yielding zones that coalesce to make up a single complex aquifer system. Most wells are completed in the upper few hundred feet and are adequate for domestic and agricultural use throughout the valley. The estimated transmissivity of the water-yielding zones is $10,000 \mathrm{ft}^{2} / \mathrm{d}$. Groundwater flow in the shallow aquifer is generally from the south, west, and north margins of the valley toward Lake Helena. Recharge to the Helena valley-fill aquifer is through infiltration of stream flow, irrigation water, and precipitation, and inflow from fractures in the surrounding and underlying bedrock. The groundwater is of the calcium bicarbonate type, which probably results from the dissolution of calcium-carbonate rocks present in the valley-fill sediments.

Local Hydrogeology. The following review is based on a study of the hydrogeology of the Fort William Henry Harrison site included in an engineering and feasibility report on the Veterans Administration water supply system by James M. Montgomery, Consulting Engineers, Inc. (1977). Work in 1977 included a review of pre-existing data; geological mapping; spring and water well location and sampling; surface water sampling; a shallow seismic survey; and the drilling, logging, and sampling of six test wells. The general geology of the site and the location of the exploratory wells are shown in Figure 3.

The oldest rocks in the area are the Precambrian argillite, feldspathic quartzite, limestone, and dolomite of the Empire, Spokane, and Helena formations that outcrop in the hills and mountains to the south, west, and north of Fort William Henry Harrison. These rocks also form the bedrock that was encountered at depths from 80 to $100 \mathrm{ft}$ in exploratory borings on the site. The contact between bedrock and the overlying pediment deposits is gradational because the pediments were formed from the local Precambrian bedrock. In general, the massive Precambrian rocks yield only small quantities of water, but at the site of exploratory well VA-3 the highly fractured bedrock showed moderate permeability.

Pediment deposits that developed at the edge of the basin during the late Tertiary and early Quaternary epochs rest on the Precambrian bedrock at Fort William Henry Harrison. The thickness and composition of the pediment material vary considerably depending on the location and the type of country rock. At the site, the pediment gravel thickness exceeds $100 \mathrm{ft}$ in places, 


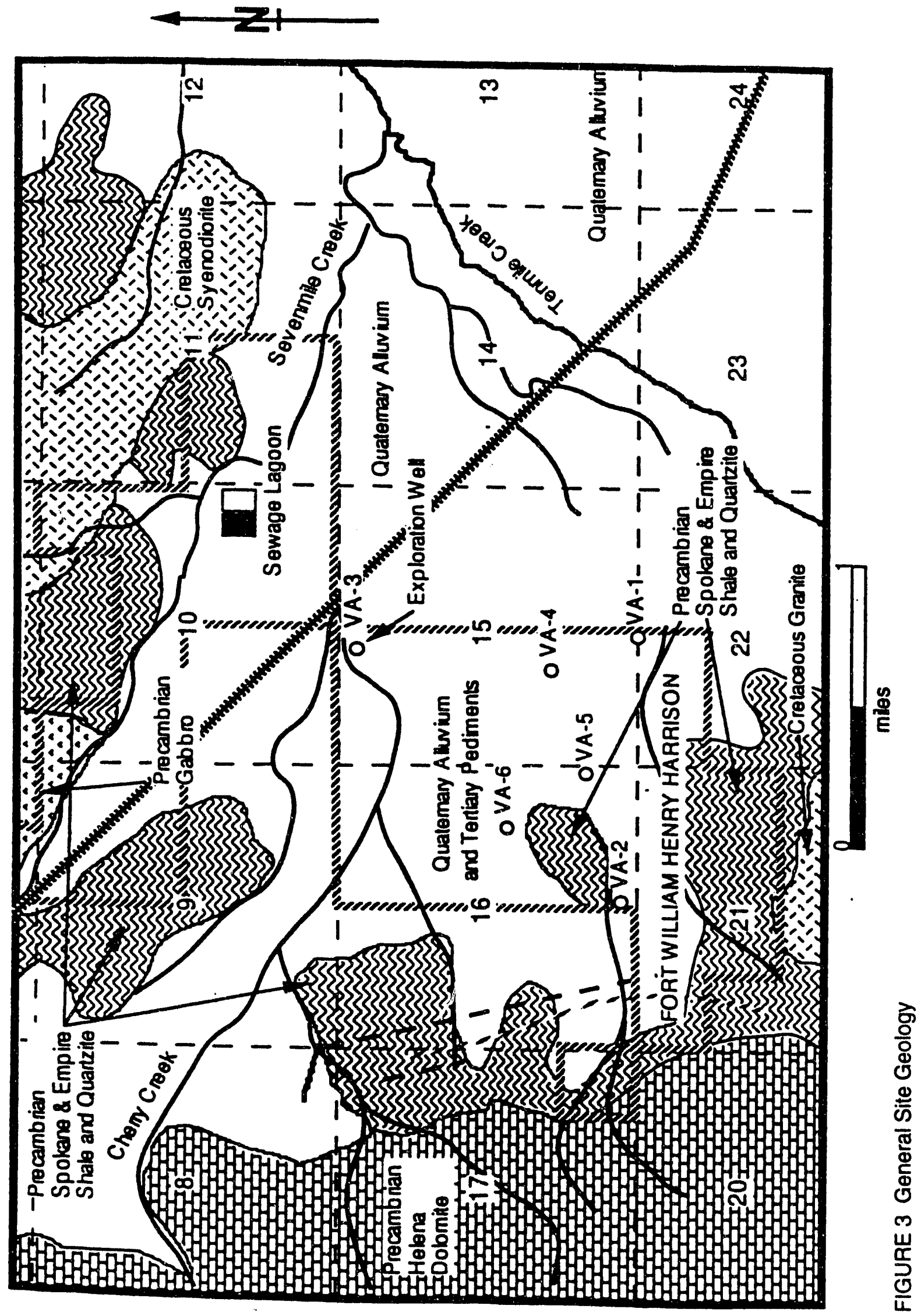


and the composition of the subrounded to subangular, pebble- to cobble-sized rock fragments includes decomposed limestone, dolomite, quartzite, and slate. In general, the pediment deposits yielded only small quantities of water, except at the location of exploratory well VA-3 where the zone was tested at $100 \mathrm{gpm}$. Tertiary shale, silt, and clay layers representing lake bed deposits were noted within the upper part of the pediment unit. The impermeable lake bed deposits are not a significant source of groundwater in this area.

Quaternary alluvial-fan deposits consisting of poorly sorted gravel, sand, silt, and clay form the uppermost unit at the site, overlying the Tertiary/Quaternary pediments. Exploratory drilling showed the alluvium to be thickest (up to $80 \mathrm{ft}$ ) at the southern end of the site near the V.A. Hospital, thinning to $17 \mathrm{ft}$ in test well VA-3 at the northeastern corner of the site. The unit yields small to moderate amounts of water from thin interbedded sands and gravels within the saturated zone.

Local Aquifer Characteristics. The principal water-bearing zones in the vicinity of Fort Harrison are Quaternary alluvium and Tertiary pediments. The unconfined Quaternary aquifer attains a maximum saturated thickness of about $70 \mathrm{ft}$ in the southern half of the site and is largely absent in the area of thin alluvial cover (less than $20 \mathrm{ft}$ thick) near the northeastern corner of the property. Test wells in the alluvial material yielded 10 to $30 \mathrm{gpm}$. The water table at the site is generally about $20 \mathrm{ft}$ below ground level.

The most significant local aquifer is found in the Tertiary pediments and fractured rock intersected in exploratory well VA-3. This well yielded $100 \mathrm{gpm}$ on a pump test from a saturated aquifer thickness of $110 \mathrm{ft}$. As a result, the northeastern corner of the Fort Harrison cantonment near VA-3 was selected as the location for two wells, with a combined peak capacity of $200 \mathrm{gpm}$, that provide irrigation water to the V.A. Hospital grounds (Sorenson \& Company 1982). The relatively high productivity of this zone may be due to an increase in permeability of the pediments from faulting, coupled with the possible existence of a hydraulic connection to the thick valley-fill alluvial deposits located in the valley of Sevenmile Creek immediately to the north.

On the basis of water level measurements made during the summer of 1975 , the direction of groundwater movement was determined to be to the northeast in the predominantly alluvial-fan aquifer that is found beneath the southern half of the site and to the southeast in the valley-fill alluvium and pediment aquifer to the north of the property (Figure 4). Flow gradients averaged 


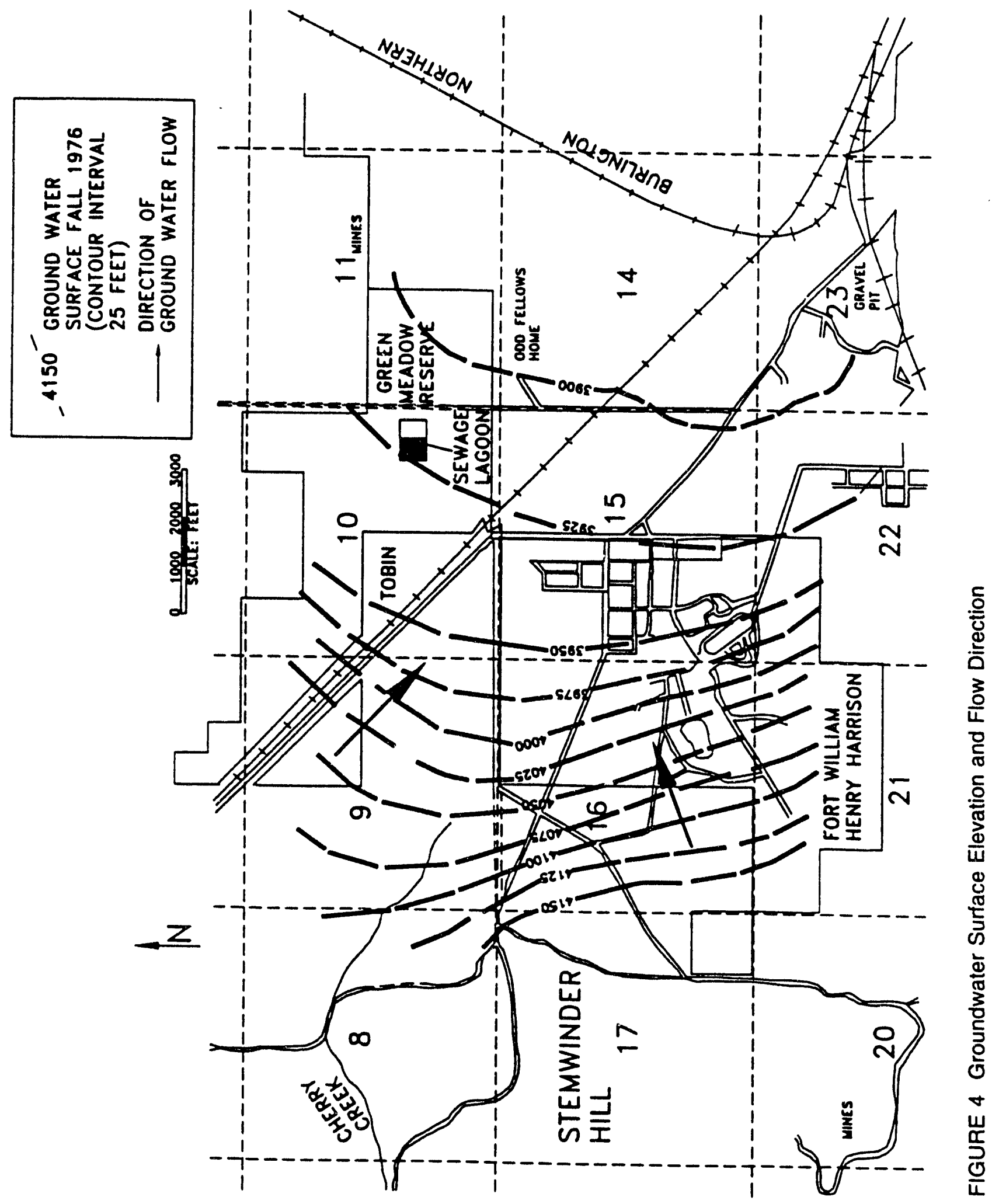


$180 \mathrm{ft} /$ mile in the southern unit and $65 \mathrm{ft} / \mathrm{mile}$ in the northern groundwater zone. Average groundwater velocities were estimated to be $400 \mathrm{ft} / \mathrm{year}$ in the southern flow unit and $3,650 \mathrm{ft} /$ year in the permeable northern zone.

Local Groundwater Quality. As part of the study of the V.A. Hospital water supply system in 1977, 15 water samples were collected from test wells, private wells, springs, Sevenmile Creek, and the Fort Harrison sewage lagoon. The samples were analyzed for the major anions and cations and, in the case of the on-site test wells, for arsenic and selenium. All samples were tested for iron. The study found that most of the samples were of the calcium-magnesium or magnesium-calcium bicarbonate type, but two were classified as sulfate groundwaters. Locally high sulfate concentrations in excess of the maximum contaminant level (MCL) of $400 \mathrm{mg} / \mathrm{L}$ for drinking water were found in a spring west of the V.A. Hospital (near test well VA-6) and in a private well $3 \mathrm{mi}$ east of Fort William Henry Harrison ( 580 and $462 \mathrm{mg} / \mathrm{L}$ sulfate, respectively). High sulfate concentrations in the groundwater are probably derived from the oxidation of pyrite $\left(\mathrm{FeS}_{2}\right)$ that is disseminated in the Precambrian sediments and in rock fragments within the Tertiary pediment deposits.

Nitrate values from groundwater in the vicinity of the site were all well below the MCL of $10 \mathrm{mg} / \mathrm{L}$ for drinking water, as was the sample from the sewage lagoon. However, nearly all of the groundwater samples exceeded the state MCL of $500 \mathrm{mg} / \mathrm{L}$ for total dissolved solids (TDS) in drinking water. These data were sonfirmed by the results of regional groundwater sampling, conducted by the USGS at various times between 1971 and 1990, that showed that water samples from wells in sections 13,14, and 15, T10N, R4W that include the Fort William Henry Harrison cantonment (west half of section 15) had a high specific conductance (most samples $>1,000 \mu \mathrm{S} / \mathrm{cm}$ ) or high TDS values ( $>500 \mathrm{mg} / \mathrm{L}$ ). Specific conductance is directly related to the concentration of dissolved solids in the groundwater sample. Elsewhere in the Helena Valley, similar values for specific conductance and TDS have been attributed to the leaching of sludge and solid waste from an old landfill and to the infiltration of sewage effluent from the city of Helena into the groundwater (Moreland and Leonard 1980). This is an unlikely scenario to explain the locally high specific conductance and TDS zone proximate to the post because a water sample from the Fort William Henry Harrison sewage lagoon was found to have a low TDS value of $246 \mathrm{mg} / \mathrm{L}$ compared to the average of $400 \mathrm{mg} / \mathrm{L}$ for the Helena Valley aquifer. As a result, infiltration of lagoon water into the local groundwater would tend to lower the specific conductance and TDS concentration of the aquifer. In the area surrounding Fort Harrison, it is more likely that the high specific conductance and TDS values are a natural consequence of groundwater in contact with 
rocks that include a high proportion of relatively soluble limestone and dolomite. In addition, precipitation in the local catchment area percolates through the Precambrian Helena dolomite that outcrops in the hills west of the property before reaching the aquifer.

In recent regional sampling of the Helena Valley aquifer by the USGS in 1991, analysis of selected localities for volatile organic compounds detected a trace of trichloroethene $(0.8 \mu \mathrm{g} / \mathrm{L}) \mathrm{in}$ 30- $\mathrm{ft}$ irrigation well located $0.5 \mathrm{mi}$ east of the cantonment. The MCL for trichloroethene (trichloroethylene or TCE) is $5 \mu \mathrm{g} / \mathrm{L}$. TCE is a common solvent used in degreasing operations.

\subsubsection{Sensitive Environments}

Several sensitive habitats and locally or state rare species are located within a 4-mi radius of Fort William Henry Harrison. The Montana Natural Heritage Program lists the following state rare plants as occurring within the 4-mi radius: rabbit-foot crazyweed (Oxytropis laopus var. conjugens), lesser rushy milkvetch (Astragalus convallarius var. convallarius), rocky mountain ragwort (Senecio debilis), a 34-acre stand of Pseudoroegneria spicata/Poa cusickii, and a 40-acre stand of bluebunch wheatgrass/needle-and-thread grass located "north of entrance road to Fort Harrison" (Montana Natural Heritage Program 1993). The only vertebrate identified as rare is a breeding colony of great blue herons (Ardea herodias) located on the southwestern corner of Lake Helena within 15 downstream mi of Fort William Henry Harrison (Montana Natural Heritage Program 1993).

Four significant habitat areas have been identified within $4 \mathrm{mi}$ of Fort William Henry Harrison: the Helena Valley Reservoir Fishing Access Site, the Lake Helena Wildlife Management Area, the Spring Meadow Lake, and the Green Meadow Game Preserve. The Helena Valley Reservoir Fishing Access Site and the Lake Helena Wildlife Management Area are located within 15 downstream mi of Fort William Henry Harrison. The former provides access to a trout fishery, and the latter is a state-managed, access-restricted waterfowl production area consisting of 2,300 acres bounding Lake Helena. The Spring Meadow Lake State Recreation Area, which includes wetlands, a stocked pond, and nature trail is located less than $1 \mathrm{mi}$ southeast of Fort William Henry Harrison. Green Meadow Game Preserve is located approximately 0.5 mi east of Fort William Henry Harrison and consists of gently rolling prairie crossed by two creeks and contains ponds and ripa ،a.! wetlands (Montana Natural Heritage Program 1993; DuWaldt 1993). 


\section{Environmentally Significant Operations}

The PA team from Argonne identified six ESOs at Fort William Henry Harrison that qualify for consideration under the IRP program: SWAREB, the Landfill Burial Cells, the Old Ordnance Burial Trench, the Scattered Pits Area, the Williams Street Gravel Pit, and the Railroad Track Stains Area (Figure 2).

\subsection{Southwest Asia Rebuild Center}

The Southwest Asia Rebuild Center (SWAREB) is housed in buildings T503 through T506 located on the east side of the cantonment. The SWAREB shop area has been used for maintenance activities for several decades and been a source of solid and hazardous waste. Of particular concern is a dry well located on the southwestern corner of the SWAREB shops (Figure 2B). This dry well is reported to have been in use at least until the mid 1950s, when shop liquid waste was disposed of through the sanitary sewer system. The dry well is no longer in use and has been plugged with concrete and capped. Its depth is unknown; however, if it was a true dry well, it probably did not exceed $20 \mathrm{ft}$ in depth $(20 \mathrm{ft}$ is the approximate depth to groundwater). When the dry well was in use, it may have received industrial solvents, paint thinners, contaminated oils, and other hazardous waste, that, once placed in the subsurface, were available to the shallow groundwater. Thus, the dry well is a potential source of a release to groundwater.

\subsection{Landfill Burial Cells}

The north-central portion of the cantonment was identified as an area of historic waste burial. It is estimated that 40 to 50 waste cells measuring $20 \times 60 \mathrm{ft}$ and 15 to $20 \mathrm{ft}$ deep were created north of the CSMS and northwest of the SWAREB. According to these estimations, the total volume of this ESO could be $1,200,000 \mathrm{ft}^{3}$. Cell size was independently confirmed by a 1968 Montana Department of Transportation aerial photograph showing an open cell in this location (Montana Department of Transportation 1993). This cell measured $93 \mathrm{ft}$ and was located in the northwestern corner of the cantonment. Interviewed post staff and the State Environmental Specialist (SES) established that solid waste interred in the Landfill Burial Cells area included 55-gal and smaller drums of suspected hazardous material. Fort William Henry Harrison has historically used several types of solvents for vehicle maintenance and other cleaning operations. Solvents known to have been used include Stoddard's solvent, 1,1,1-trichloroethane. 
trichloroethene, and paint thinners. Post officials have stated that waste oil generated at Fort William Henry Harrison was sent to the county for road maintenance, so drums buried in this ESO likely contain other waste liquids. Interviewed MTARNG personnel who participated in the burial operations confirmed that 55-gal and other drums were placed in the cells, and one individual recorded such placement in a photograph provided by the SES for review (DuWaldt 1993). In addition to the allegations of probable hazardous waste burial, the USGS has recently shown that halogenated solvent contamination exists in the groundwater east (downgradient) of this ESO (see Section 4.1, Releases to Groundwater) (Briar and Madison 1992).

\subsection{Old Ordnance Burial Trench}

The Old Ordnance Burial Trench, as described in Section 2.2.5, was an area within the cantonment where ordnance from surrounding ranges was interred in one or possibly two elongated trenches. Depth of the burial is unknown. Interviews with Fort William Henry Harrison staff suggest that projectiles containing small amounts of high explosive were buried in the trench(es) (DuWaldt 1993). The time frame for this disposal activity is not precisely known but probably dates to the last 25 years.

\subsection{Scattered Pits Area}

The Scattered Pits Area is located due west of the SWAREB buildings in the northeastern portion of the cantonment. It is alleged that the location was used to excavate a series of pits (size and number unknown) for burial of solid waste. This area was identified as distinct from the Old Ordnance Burial Trench to the west and the Williams Street Gravel Pit directly to the north. Inspection of the ground surface during the site visit did not reveal any information on the location, size, or number of pits.

\subsection{Williams Street Gravel Pit}

Currently used for vehicle rapid decontamination exercises (Section 2.2.4), the Williams Street Gravel Pit was identified by the SES as an area of possible historical waste disposal. The coarse sizing of subsurface material (gravel with cobbles) in this area suggests that any release would rapidly migrate vertically. Although a walk-over of the area during the site visit did not reveal the presence of stains or potential hazardous waste, some metal debris was found scattered 
on the surface. Coupled with 1959 aerial photography that shows a large (200 ft in diameter) area of concentrated solid waste on the surface near the gravel pit location, and recent USGS sampling data showing halogenated solvent contamination in a downgradient well, it is concluded that the Williams Street Gravel Pit could be a potential source of a CERCLA release.

\subsection{Railroad Track Stains Area}

Aerial photographs from 1959 and 1968 show an area of surfate staining next to the two railroad siding tracks located on the east side of the SWAREB buildings within the cantonment. The post historian suggested that this railroad siding was used to off-load equipment and supplies and may have been the site of hazardous material and petroleum, oil, and lubricants spills. Although not conclusive, aerial photography supports this allegation. Records of material delivered via railroad are not available. 


\section{Known and Suspected Releases}

\subsection{Releases to Groundwater}

Currently, no releases to groundwater from ESOs have been confirmed, except for the CSMS fuel release in 1987. This release has been remediated, and no further cleanup actions are scheduled (see Section 2.2.2). Historical aerial photography coupled with a ground photograph showing drum burial and interviews with long-time post personnel suggest that commonly used solvents and other potentially iazardous solid waste were buried at one location and could have been buried at three other locations within the cantonment. Two other ESOs, the Railroad Track Stains Area and SWAREB, are also potential contributors to groundwater contamination that may have resulted from inficication of surface spills into the underlying coarse alluvium at the on-site railroad siding, and from liquid waste disposal into a dry well at SWAREB.

Concern for groundwater near Fort William Henry Harrison is amplified by the recent publication of groundwater monitoring well data by the USGS showing that a well located approximately on the SW 1/4, SW 1/4, SW 1/4, NW 1/4 of Section 14, Town 10N, Range $4 \mathrm{~W}$, or $0.5 \mathrm{mi}$ downgradient (east) from the post, contained 0.8 parts per billion trichloroethene (Briar and Madisor. 1992). Because no intervening sources were found during this study, it is possible that Fort William Henry Harrison may be the source of this contamination.

\subsection{Releases to Surface Water}

No releases of contaminants to surface water are known or suspected. A visual inspection of ESOs conducted during the site visit suggests that no sign: ficant surface water contamination or leachace outfall exist. Intermittent streambeds and storm water accumulation areas observed during the site visit did not shown any telliale staining or areas of chemically stressed vegetation.

\subsection{Releases to Soil}

Known releases to soil include interview and photographic evidence of solid and potentially hazardous waste buried in the Landfill Burial Cell ESO. 
Potential releases to soil on the basis of interview allegations of past disposal practices include the buried ordnance and other unknown solid waste in the Old Ordnance Burial Trench, Williams Street Gravel Pit, Scattered Pits Area, and Railroad Track Staitis Area. Neither the CSMS UST fuel spill nor the former Burn Pit area located on the Live Fire Ranges is considered to be a source of contamination because each has been adequately remediated.

\subsection{Releases to Air}

No known releases to the air pathway exist. However, a significant on-site population exists at the post, and wind-mediated movement of surface contaminants if surface contamination exists at any of the six identified ESOs could cause exposure to human receptors and nearby sensitive environments.

\subsection{Other Releases}

No other significant releases of contamination to the environment have been identified for Fort William Henry Harrison, with the possible exception of alleged leakage from the sewage lagoon located on the Head $R$ ans $h$ annex to Fort William Henry Harrison, located approximately 0.33 mi northeast of the cantonment. MTARNG State Environmental Specialist personnel stated that Environmental Compliance Assessment auditors were concerned with the small steady-state volume of waste water contained in the two lagoon system. On the basis of a review of waste water generation rate, more volume should have be n present in the number 2 lagoon, leading to speculation that bottom integrity had been compromised and waste water was infiltrating the subsurface. A 1968 aerial photograph also shows the number 2 lagoon dry, suggesting that either the problem is long-term or is not significant. If a significant leakage has occurred since at least 1968, downgradient/downstream effects shuuld have been evident. Currently, no known impacts have been reported by adjacent landowners, diminishing the concern over this possible release. If, however, a release is occurring, it should be addressed under the Clean Water Act as an unpermitted release from a publicly owned treatment plant. 


\section{Human and Environmental Receptors}

\subsection{Groundwater}

Groundwater and surface water both provide drinking water for residents of the Helena Valley. Fort William Henry Harrison and the V.A. complex adjacent to it receive drinking water via the city of Helena municipal water supply system. Although this system supplies the post, the V.A. Hospital, and residents of the city, a number of residential areas and hamlets outside the city limits are self-supplied, generally through groundwater wells.

The city of Helena water supply system relies on mountain reservoirs located west of Helena and Fort William Henry Harrison and a river intake through a diversion canal at the Missouri River some $14 \mathrm{mi}$ east of Helena. The Missouri River source is downstream of Fort William Henry Harrison; however, the distance exceeds $15 \mathrm{mi}$ and the intake cannot be considered in the PA. This source is secondary to the Tenmile System and is used only during summer peak use conditions. The Tenmile System is located $10 \mathrm{mi}$ west of Fort William Henry Harrison at an elevation approximately 1,000 ft above the post, significantly upslope from the effects of any release sources being considered here.

Groundwater population targets were estimated by using recent USGS 7.5-minute topographic maps and city of Helena water service maps to identify the number of residences outside of city service but within a four-mile radius of the installation. Estimates were calculated by house counts from topographic maps multiplied by the average county household size (2.2 individuals/residence) (U.S. Department of Commerce 1993). Within a four-mile radius of Fort William Henry Harrison are two-thirds of the city of Helena and approximately 1,000 residences in unincorporated areas, including 10 residences that use shallow groundwater wells for drinking water and are located downgradient and within $1 \mathrm{mi}$ of Fort William Henry Harrison. Figure 5 shows the location of wells in the Helena Valley east and downgradient of Fort William Henry Harrison. The difference between the number of wells shown in Figure 5 and the approximate number of residences in unincorporated portions of the Helena Valley is explained by well size. Some wells are sized to serve multiple residences, although Figure 5 does not distinguish multiple household wells from single family wells. These 10 residences constitute the primary target population; that is, those residents who are close enough to known contamination that they could have been exposed. 


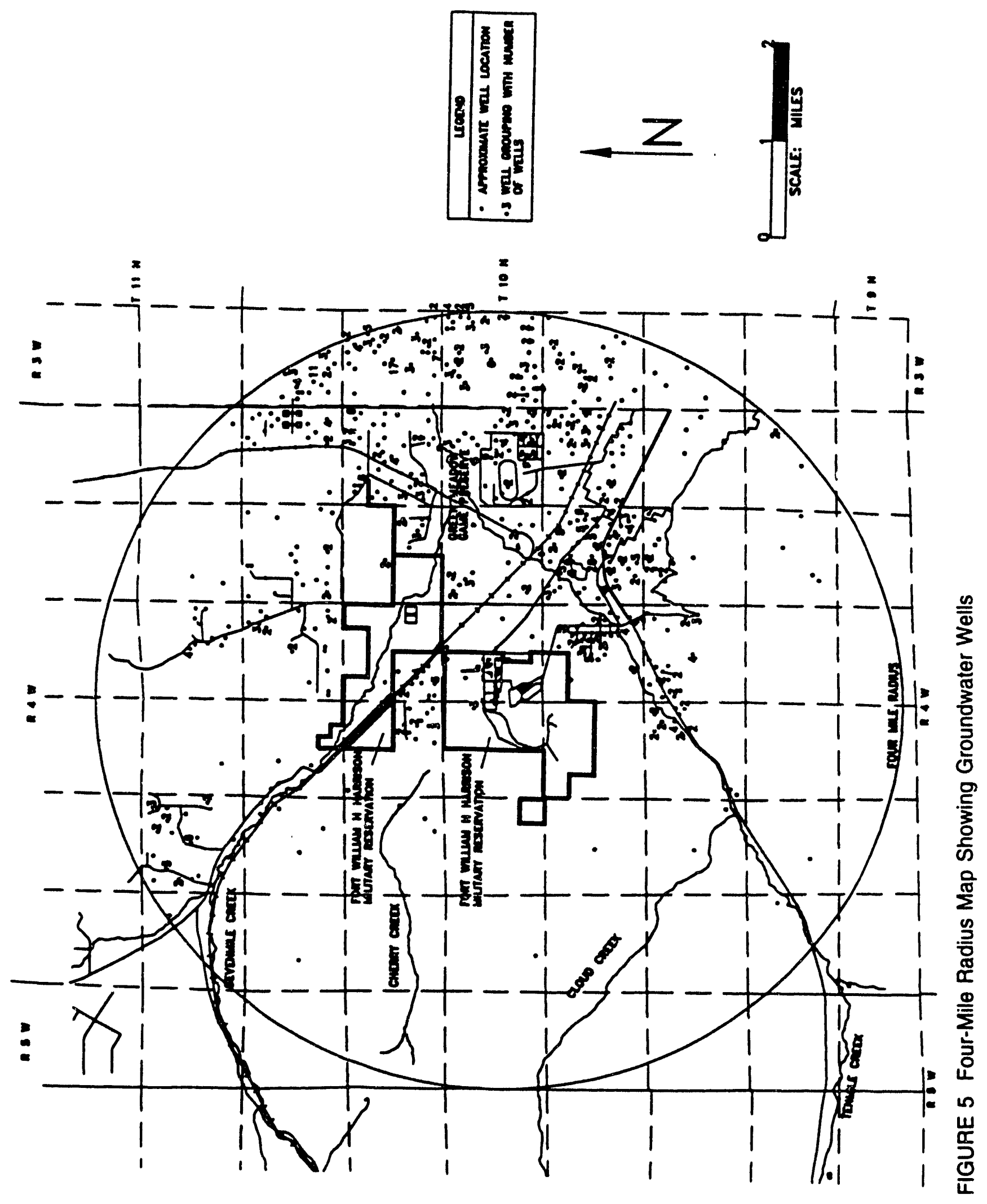




\subsection{Surface Water}

No human receptors are directly associated with the two perennial streams located near Fort William Henry Harrison. Tenmile Creek and Sevenmile Creek flow past the post and empty into the Missouri River. Although no drinking water withdrawal occurs from these streams within the 15-mi target limit distance, Tenmile Creek supports a trout fishery, and human exposure to contaminants could occur via fish consumption. Both streams also support riparian wetlands, and Sevenmile Creek flows into Lake Helena, which supports a blue heron rookery.

\subsection{Soil}

Soil contamination receptors are limited to the on-site population at Fort William Henry Harrison and nearby sensitive environmental features such as historic buildings at the V.A. Hospital and the state game preserve located adjacent to the eastern boundary of the post.

\subsection{Air}

The human population at Fort William Henry Harrison is subject to windblown material, particularly particulates from range activities and outdoor maintenance activities. However, no surface contamination releases available to dispersion via the air pathway have been identified, so the potential for post or off-post receptor contamination via the air pathway is limited.

\subsection{Other Receptors}

No other receptors of contamination from Fort William Henry Harrison have been identified. 


\section{Preliminary Assessment Findings and Conclusions}

\subsection{Summary of Preliminary Assessment Findings}

Fort William Henry Harrison is a 1,592-acre post located 1.5 mi northwest of Helena, Montana. This study has established the presence of six ESOs that were used to dispose of potentially hazardous waste. These six areas, the SWAREB, the Landfill Burial Cell, Old Ordnance Trench, Scattered Pits Area, Williams Street Gravel Pit, and Railroad Track Stains Area, are all located within the Fort William Henry Harrison cantonment. Interviewed employees, photographs of burial activities, and historic aerial photographs established that drums of unknown content were buried in at least one of these locations (Landfill Burial Cells), and that a dry well at SWAREB was used to dispose of liquid wastes. This information in conjunction with recent downgradient groundwater sampling data showing the presence of trichloroethene in a 30-ft irrigation well suggests that Fort William Henry Harrison may have released CERCLA contaminants to the shallow groundwater. This finding is significant because groundwater downgradient from the post is used for drinking water by all nearby residents.

\subsection{Recommendations for Further Action}

The primary objective of the PA is to identify and evaluate ESOs that would result in either (1) immediate action, (2) site investigation, or (3) no further PA/IRP action. Generally, the available information indicates that Fort William Henry Harrison presents a moderate, near-term threat to human health and the environment. The history of multiple waste burial areas in the cantonment coupled with relatively permeable alluvial surface deposits, a relatively high water table, and analytical evidence of halogenated solvent contamination in a near-site, downgradient well suggest that the site could have contaminated groundwater with chemical wastes. Because the shallow groundwater near the site is used by local residences, steps should be taken to confirm the location of any contaminated aquifer materials and the source or sources of contamination. Initially, the known contaminated well should be resampled to confirm the original finding, and soil gas and/or auger/hydropunch-type technology should be used to establish a groundwater sampling grid of analytical data to confirm any plume(s) and establish the source of contamination. As part of the site investigation, all six potential source areas, the SWAREB dry well, the Landfill Burial Cells, Old Ordnance Trench, Scattered Pits Area, Williams Street Gravel Pit, and Railroad Track Stains Area, should be sampled to determine if they are sources of contaminant releases to groundwater. 
It is also recommended that a second type of data collection occur concurrent with the release determination. If field analytical results from groundwater sampling establish a release(s) from Fort William Henry Harrison, all other data needed to process a revised HRS package for the site should be collected at this time. In general, this includes detailed information characterizing the volume of the source area, the location of receptors, and the concentration of any release contaminants in environmental media that receptors are exposed to, for example, drinking water, consumable fish, and wetland soils contamination, as appropriate for the pertinent pathways. 


\section{References}

Briar, D.W., and J.P. Madison, 1992, Hydrogeology of the Helena Valley-Fill Aquifer System,

West-Central Montana, U.S. Geological Survey Water-Resources Investigations Report 92-4023, Helena, Montana.

Cordell, G.V., 1971, The Climate of Montana, in Climates of the States; Volume II - Western States Including Alaska and Hawaii; National Oceanic and Atmospheric Administration, U.S. Department of Commerce; Water Information Center, Inc.

DuWaldt, J., 1993, Fort William Henry Harrison Preliminary Assessment Field Notes, Argonne National Laboratory, Denver, Colorado (March).

Fort William Henry Harrison Facilities Management Office, 1993, Master Plan, Fort William Henry Harrison, Helena, Montana, Major Training Area.

James M. Montgomery, Consulting Engineers, Inc., 1977, Engineering Feasibility and Economic Study of the Water Supply System: V.A. Center, Fort Harrison, Montana (May).

Lorenz, H.W., and F.A. Swenson, 1951, Geology and Ground-Water Resources of the Helena Valley, Montana, U.S. Geological Survey Circular 83, Helena, Montana.

Montana Department of Military Affairs, 1987, Letter report to the State of Montana Department of Health and Environmental Sciences, Solid and Hazardous Waste Bureau, Helena, Aug. 17.

Montana Department of Transportation, 1993, Aerial Photograph 1968 and 1959 Series, Fort William Henry Harrison, Helena, Montana.

Montana Natural Heritage Program, 1993, 9 Element Occurrences and 4 Management Summaries, The Nature Conservancy and Montana State Library, Helena, Montana.

Moreland, J.A., and R.B. Leonard, 1980, Evaluation of Shallow Aquifers in the Helena Valley, Lewis and Clark County, Montana, U.S. Geological Survey Water-Resources Investigations, Open-File Report 80-1102, Helena, Montana. 
Sorenson \& Company, 1982, Engineering Report: Water :stem Improvements: Veterans Administration Center, Fort Harrison, Montana, Project No. 82-03-05 (October).

State of Montana, Department of Military Affairs, 1990, Fort William Henry Harrison, Helena, Montana, A Capsule of History of the Post, Department of Military Affairs, Office of the Adjutant General, State of Montana, Helena.

U.S. Department of Commerce, 1993, 1990 Census of Housing Block Statistics, Bureau of the Census, Data Users Division, Washington, D.C.

U.S. Environmental Protection Agency, 1991, Guidance for Performing Preliminary Assessments under CERCLA, Publication 9345.0-01A, Office of Emergency and Remedial Response, Office of Solid Waste and Emergency Response, Washington, D.C. 


\section{Appendix:}

Interview Information 


\section{Appendix:}

\section{Interview Information}

\section{Individuals Interviewed}

State Environmental Specialist

Montana Department of Military Affairs

Helena, Montana

State Environmental Specialist

Montana Department of Military Affairs

Helena, Montana

Facilities Management Officer

Montana Army National Guard

Fort William Henry Harrison, Montana

Command Historian

Montana Army National Guard

Helena, Montana
Range Officer

Montana Army National Guard

Fort William Henry Harrison, Montana

Director of Public Works

City of Helena

Helena, Montana

Montana Army National Guard

Fort William Henry Harrison, Montana

\section{Argonne Investigators}

John A. DuWaldt

(303) 986-1140

Tim Meyer

(708) 252-5781 


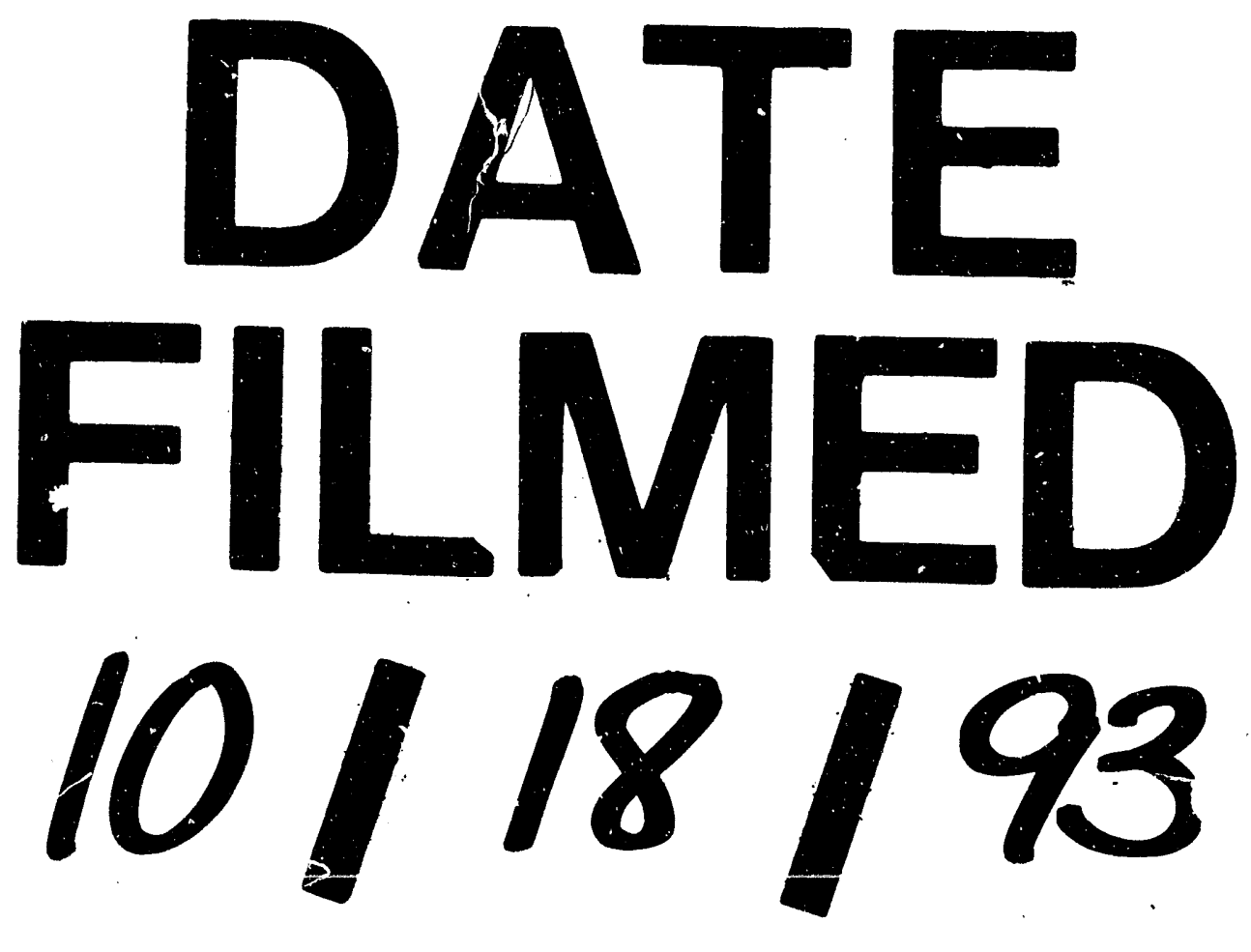


